\title{
Regional aerosol optical properties and radiative impact of the extreme smoke event in the European Arctic in spring 2006
}

\author{
C. Lund Myhre ${ }^{1}$, C. Toledano ${ }^{2}$, G. Myhre ${ }^{3,4}$, K. Stebel ${ }^{1}$, K. E. Yttri ${ }^{1}$, V. Aaltonen ${ }^{5}$, M. Johnsrud ${ }^{1}$, M. Frioud ${ }^{6}$, \\ V. Cachorro $^{2}$, A. de Frutos ${ }^{2}$, H. Lihavainen ${ }^{5}$, J. R. Campbell ${ }^{7}$, A. P. Chaikovsky ${ }^{8}$, M. Shiobara ${ }^{9}$, E. J. Welton ${ }^{10}$, and \\ K. Tørseth ${ }^{1}$ \\ ${ }^{1}$ Norwegian Institute for Air Research, P.box 100, 2027 Kjeller, Norway \\ ${ }^{2}$ Grupo de Óptica Atmosférica (GOA-UVA), Universidad de Valladolid, Spain \\ ${ }^{3}$ Department of Geosciences, University of Oslo, Norway \\ ${ }^{4}$ Center for International Climate and Environmental Research - Oslo, Norway \\ ${ }^{5}$ Finnish Meteorological Institute, Helsinki, Finland \\ ${ }^{6}$ ALOMAR/Andøya Rocket Range, Andenes, Norway \\ ${ }^{7}$ University of Alaska Fairbanks, Fairbanks, USA \\ ${ }^{8}$ Institute of Physics, National Academy of Sciences, Minsk, Belarus \\ ${ }^{9}$ National Institute of Polar Research, Tokyo, Japan \\ ${ }^{10}$ NASA Goddard Space Flight Center, Greenbelt, Maryland, USA
}

Received: 23 May 2007 - Published in Atmos. Chem. Phys. Discuss.: 3 July 2007

Revised: 4 October 2007 - Accepted: 13 November 2007 - Published: 28 November 2007

\begin{abstract}
In spring 2006 a special meteorological situation occurred in the European Arctic region giving record high levels of air pollution. The synoptic situation resulted in extensive transport of pollution predominantly from agricultural fires in Eastern Europe into the Arctic region and record high air-pollution levels were measured at the Zeppelin observatory at $\mathrm{Ny}$-Ålesund $\left(78^{\circ} 54^{\prime} \mathrm{N}, 11^{\circ} 53^{\prime} \mathrm{E}\right)$ in the period from 25 April to 12 May. In the present study we investigate the optical properties of the aerosols from this extreme event and we estimate the radiative forcing of this episode.

We examine the aerosol optical properties from the source region and into the European Arctic and explore the evolution of the episode and the changes in the optical properties. A number of sites in Eastern Europe, Northern Scandinavia and Svalbard are included in the study. The observations show that the maximum AOD was from 2-3 May at all sites and varies from 0.52 to 0.87 , and the corresponding Ångstrøm exponent was relatively large. Lidar measurements from Minsk, ALOMAR (Arctic Lidar Observatory for Middle Atmosphere Research at Andenes) and $\mathrm{Ny}$ Ålesund show that the aerosol layer was below $3 \mathrm{~km}$ at all sites the height is decreasing from the source region and into the Arctic. For the AERONET sites included (Minsk, Toravere, Hornsund) we have further studied the evolution of the aerosol size. The single scattering albedo at Svalbard is pro-
\end{abstract}

Correspondence to: C. Lund Myhre

(clm@nilu.no) vided for two sites; Ny-Ålesund and Hornsund. Importantly the calculated single scattering albedo based on the aerosol chemical composition and size distribution from $\mathrm{Ny}$-Ålesund and the AERONET measurements at Hornsund are consistent. We have found strong agreement between the satellite daily MODIS AOD and the ground-based AOD observations. This agreement is crucial for accurate radiative forcing calculations. We calculate a strong negative radiative forcing for the most polluted days employing the analysed ground based data, MODIS AOD and a multi-stream model for radiative transfer of solar radiation. During this specific pollution event the forcing reached values as low as $-35 \mathrm{~W} \mathrm{~m}^{-2}$ in the region. For comparison, the direct forcing of a corresponding aerosol layer with a typical AOD of 0.05 for the season is around $-5 \mathrm{~W} \mathrm{~m}^{-2}$.

\section{Introduction}

In the investigations of climate change, aerosols are of vital interest, as they have a direct impact on the radiative balance by scattering of solar radiation and absorption of solar and thermal radiation. The dominating process depends on the absorption and scattering characteristics of aerosols, which is a function of their composition, shape, size, and phase. Calculations of the direct effect of aerosols have a high level of uncertainty despite the huge scientific focus during the last decades (IPCC, 2007). Bellouin et al. (2005) have estimated

Published by Copernicus Publications on behalf of the European Geosciences Union. 
the global aerosols direct radiative forcing in 2002 based on satellite measurements. They calculate an all sky direct radiative forcing (DRF) of $-0.8 \mathrm{~W} \mathrm{~m}^{-2}$ with a standard deviation $(\sigma)$ of \pm 0.1 , indicating a significantly stronger DRF than present model estimates. The forcing is strongest over land though also connected with the highest uncertainty in these areas. This is explained by the high mean aerosol optical depth (AOD) over land at $550 \mathrm{~nm}$ of $0.13 \pm 0.02$. A recent joint model study of the DRF since pre industrial times has provided new estimates based on nine global models with comprehensive aerosol modules (AeroCom) (Schulz et al., 2006). The AeroCom study gave a global all sky DRF annual estimate of $-0.2 \mathrm{~W} \mathrm{~m}^{-2}$ with a $\sigma= \pm 0.2$. These two studies clearly emphasize the large uncertainty still connected with the direct radiative effect of anthropogenic aerosols in the atmosphere.

DRF requires special attention in the polar region due to the surface conditions. Ice and snow give rise to high albedos, whereas liquid water and ocean have a low albedo. As a consequence, the importance of light-absorbing aerosols is even larger in the Arctic than elsewhere, as atmospheric absorption is enhanced by the high surface albedo of snow and ice. Furthermore, the albedo of snow and ice may be reduced by deposition of black carbon (BC) containing aerosols (Hansen and Nazarenko, 2004). The total effect of anthropogenic aerosols in this region is largely uncertain and few studies are available (Quinn et al, 2007). At present, local and regional anthropogenic sources are almost absent in the Arctic region. Nevertheless Arctic haze, commonly present in springtime, is a well-known result of long-range transport from mid-latitude sources in Russia, Europe and North America (Stohl et al., 2006; Quinn et al., 2007; Law and Stohl, 2007). In combination with transport, favourable meteorological conditions with strong inversion in late winter and spring and little precipitation result in the high aerosol levels (Quinn et al., 2007, and references therein), while the dominating light-absorbing aerosols transported into the region are black carbon containing aerosols from fossil fuel combustion. A recent study demonstrated that aerosols from biomass burning (BB) are a more important source of BC than previously thought (Stohl et al., 2006). To quantify the aerosol influence on the atmospheric radiative balance, knowledge of the AOD and single scattering albedo (SSA) is required (Hansen et al., 1997). SSA is a measure of an aerosol's scattering efficiency. A SSA of 1 indicates a fully scattering aerosol with a strong cooling effect. Low SSA values indicate a heating effect. Haywood and Shine (1995) showed that the critical turnover value of the SSA, where the DRF changes sign, is largely dependent on the surface reflectance. In the Arctic region, which has a high surface reflectance the turnover value would be high, implying that even moderate levels of absorbing aerosols might heat the atmosphere in this region. In fact, Pueschel and Kinne (1995) propose aerosols with SSA values as high as 0.98 may still have a heating effect on the atmosphere in this region.
In spring 2006 a special meteorological situation occurred in the European Arctic region, which resulted in record high level of pollution (Stohl et al., 2007; Treffeisen et al., 2007). The monthly mean temperatures for January, April and May were the highest ever recorded. The synoptic situation resulted in extensive transport of pollution into the region, and record high air-pollution levels were measured at the Zeppelin observatory in Ny-Ålesund. A detailed description of the mechanisms controlling the transport and the pollution levels in Ny-Ålesund is presented in Stohl et al. (2007). They find that the relationship between the high temperatures and the extensive pollution is caused by a combination of to factors. Firstly, the high temperatures in the Arctic reduced the temperature difference between the pollution source region and the Arctic; thereby makig low-level transport of the pollution possible. Secondly, the general pressure systems in the Northern hemisphere during the spring period were of vital importance.

The record levels were observed at the end of April and in the beginning of May, with maximum values of AOD of 0.68 at $500 \mathrm{~nm}$ on the 2 May. This is the highest value measured since the beginning of the measurements in 1991. A comparable mean Arctic haze level is 0.133 at $532 \mathrm{~nm}$, and the spring background level is 0.071 for the period 1991-1999 (Herber et al. 2002). Stohl et al. (2007) concluded that the origin of the pollution event was dominated by agricultural fires in Eastern Europe, also expanding to forest fires in some areas. The maximum daily mean concentration of particulate matter with diameter less than $0.7 \mu \mathrm{m}$ (noted as $\mathrm{PM}_{0.7}$ ) estimated from differential mobility particle sizer (DMPS) measurements was $29 \mu \mathrm{g} \mathrm{m}^{-3}$ on the 3 May. Ozone $\left(\mathrm{O}_{3}\right)$ and carbon monoxide $(\mathrm{CO})$ reached values of $83 \mathrm{ppb}$ and in excess of $250 \mathrm{ppb}$, respectively, which is the highest ever measured at the observatory. In fact, the previously maximum hourly $\mathrm{O}_{3}$ concentration ever recorded since the measurements started in 1989 were $61 \mathrm{ppb}$, clearly illustrating the extremity of this event.

In the present study, we investigate the optical properties of the aerosols from the extreme smoke transport event in spring 2006. We examine the aerosol optical properties from the source region and into the Arctic in order to explore the evolution of the plume and possible changes in optical properties. A number of sites located in Eastern Europe, Northern Scandinavia and Svalbard allow for a regional characterization of the aerosol optical properties by means of remote sensing instruments. Additionally, we use daily MODIS AOD products when available. The use of satellite data allows for a more complete picture of the episode and its evolution in time and space. Based on the collected data sets of AOD from ground-based and MODIS instruments, single scattering albedos, height profiles of the aerosols, and in situ observations of the aerosol chemical composition in $\mathrm{Ny}$-Ålesund, we estimate the regional direct radiative forcing (DRF) of the aerosols from the extreme episode and compare it to the DRF for typical aerosol spring levels in the Arctic. 


\section{Instrumentation and measurements}

The location of the sites included in this study is shown in Fig. 1. The information about the instruments and available data products is summarized in Table 1 . We have collected data from three AERONET (Aerosol Robotic Network) (Holben et al., 1998) sites namely Hornsund (Svalbard, Norway), Minsk (Belarus) and Toravere (Estonia). Spectral AOD and the AERONET inversion products from sun photometer measurements (size distribution, single scattering albedo, complex refractive index) are available for these sites (Dubovik et al., 2000). The data are collected with the standard network Cimel sun photometer, which provides direct sun and sky radiance measurements at seven spectral channels in the range $340-1020 \mathrm{~nm}$. The sites in Minsk and Toravere are both located close to the source region where the biomass burning occurred and in the pathway of the plume toward Scandinavia. Hornsund is located on Spitsbergen (Svalbard), where the aerosol plume arrived after several days and more than $2000 \mathrm{~km}$ of atmospheric transport.

Four more sites, Oslo, ALOMAR, Sodankylä and NyÅlesund, providing ground-based AOD observations are located in the pathway of the plume. This allows for an investigation of the aerosol optical properties of the plume and how they are modified during the transport from the source region and into the Arctic. In Oslo and at ALOMAR Brewer spectroradiometers, designed for UV irradiance measurements and total ozone determination, are used to derive AOD at $320 \mathrm{~nm}$ (Cheymol et al., 2006). We estimate the uncertainty in AOD to be \pm 0.05 based on comparison with a Cimel instrument at ALOMAR. The Cimel instrument is now permanently located at ALOMAR. Unfortunately, at the time period of the smoke episode the instrument was removed for calibration. Despite the limited accuracy of the Brewer AOD it allows a good tracking of the episode development at these two locations.

At Sodankylä Observatory, northern Finland, the Finnish Meteorological Institute (FMI) has conducted AOD measurements with a Precision Filter Radiometer (PFR) since 2004. AOD is determined at four spectral channels, as recommended by WMO; 368, 412, 500 and $862 \mathrm{~nm}$ (Wehrli, 2000; McArthur et al., 2003). Sodankylä Observatory is part of the Pallas-Sodankylä Global Atmosphere Watch (GAW) station. For details about the other activities at Sodankylä, see Gómez-Amo et al. (2006). Complementary data used for interpretation of the Sodankylä AOD retrievals are based on in situ measurements conducted at the Pallas GAW station, $125 \mathrm{~km} \mathrm{NW}$ of Sodankylä. These include measurements of aerosol size number distribution and scattering coefficients. Hatakka et al. (2003), describe the measurements carried out at Pallas in detail.

In $\mathrm{Ny}$-Ålesund the spectral AODs were measured with a sky-radiometer, Model POM-02 manufactured by Prede Co., Tokyo. The instrument was placed on the roof-top of the

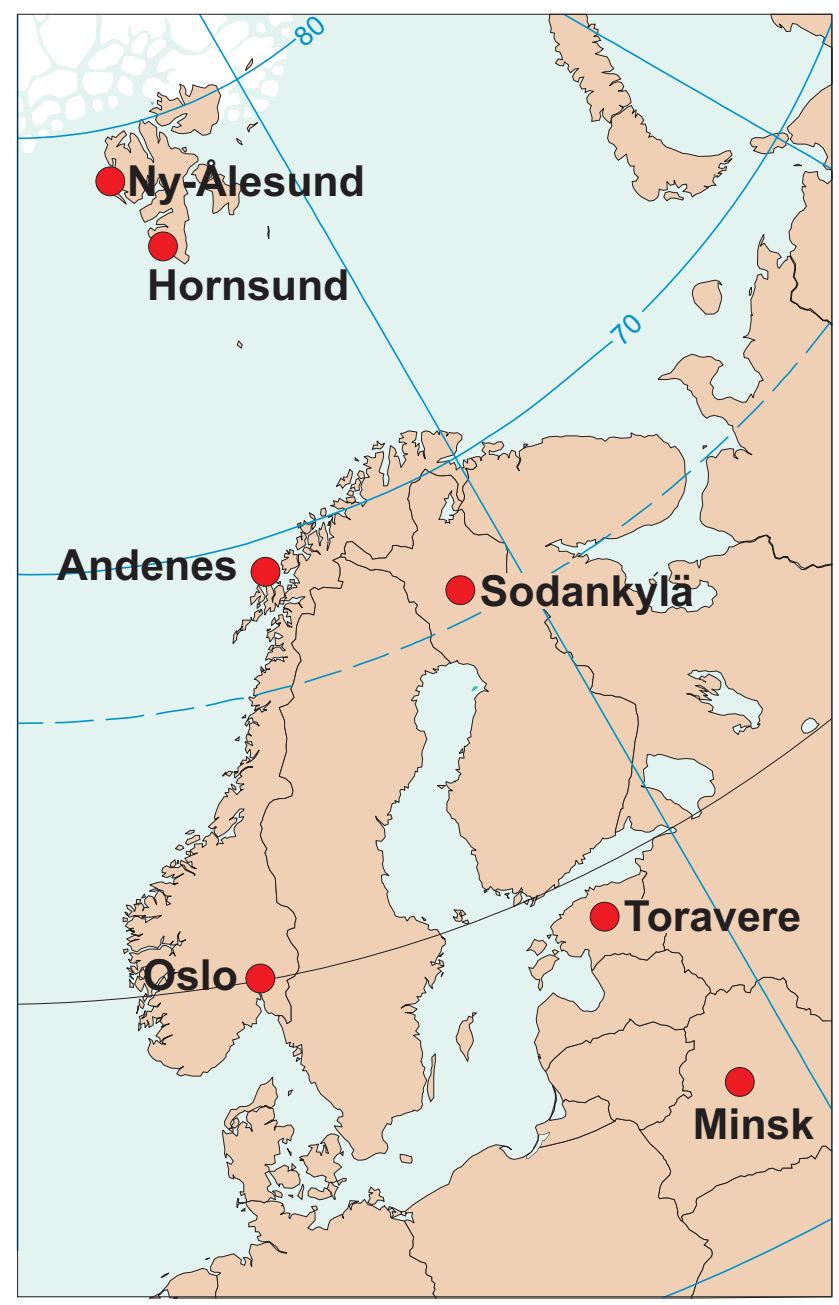

Fig. 1. The map shows the location of the measurement sites included in the study.

Rabben Station building in Ny-Ålesund. The sky-radiometer includes 11 channels at 315, 340, 380, 400, 500, 675, 870, $940,1020,1600$ and $2200 \mathrm{~nm}$. The AODs were calculated for 5 wavelengths at $400,500,675,870$ and $1020 \mathrm{~nm}$. The accuracy of AODs obtained here is expected to be better than \pm 0.005 .

For Ny-Ålesund we have also included the AOD measurements of the sun photometer SP1A at the AWIPEV station (The Alfred Wegener Institute for Polar and Marine Research) presented in Stohl et al. (2007).

Clouds, especially thin and steady cirrus clouds, cause erroneously high AOD values hence cloud-affected measurements are screened from the data series. For the sites in Minsk, Toravere and Hornsund the AERONET automatic cloud-screening algorithm have been used (Smirnov et al., 2000). For Sodankylä the PFR-GAW (Wehrli, 2000; Smirnov et al., 2000; Harrison et al., 1994) automatic cloudscreening algorithms have been employed. For the data obtained from the Prede sky-radiometer in Ny-Ålesund the 
Table 1. Summary of sites, instruments and data products.

\begin{tabular}{|c|c|c|c|}
\hline Site & Coordinates & Instrument & Products \\
\hline ALOMAR & $69^{\circ} 16^{\prime} \mathrm{N}$ & Lidar & AOD $320 \mathrm{~nm}$, Backscatter profiles \\
\hline (Andenes) & $16^{\circ} 00^{\prime} \mathrm{E}$ & Brewer & at $532 \mathrm{~nm}$ \\
\hline Hornsund & $\begin{array}{l}77^{\circ} 00^{\prime} \mathrm{N} \\
15^{\circ} 33^{\prime} \mathrm{E}\end{array}$ & Cimel & $\begin{array}{l}\text { AOD ( } 7 \text { channels } 340-1020 \mathrm{~nm}) \text {, } \\
\text { Ångström exponent, single scat- } \\
\text { tering albedo }\end{array}$ \\
\hline Minsk & $\begin{array}{l}53^{\circ} 55^{\prime} \mathrm{N} \\
27^{\circ} 36^{\prime} \mathrm{E}\end{array}$ & $\begin{array}{l}\text { Lidar } \\
\text { Cimel }\end{array}$ & $\begin{array}{l}\text { AOD ( } 4 \text { channels } 440-1020 \mathrm{~nm}) \text {, } \\
\text { Ångström exponent, single scat- } \\
\text { tering albedo, Backscatter profiles } \\
\text { at } 532 \mathrm{~nm}\end{array}$ \\
\hline Ny-Ålesund & $\begin{array}{l}78^{\circ} 54^{\prime} \mathrm{N} \\
11^{\circ} 53^{\prime} \mathrm{E}\end{array}$ & $\begin{array}{l}\text { Lidar } \\
\text { SP1A }\end{array}$ & $\begin{array}{l}\text { AOD }(17 \text { channels } 350-1065 \mathrm{~nm}) \\
\text { Ångström exponent, backscatterer } \\
\text { profiles at } 523.5 \mathrm{~nm} \text {, chemical and } \\
\text { physical properties }\end{array}$ \\
\hline Ny-Ålesund & $\begin{array}{l}78^{\circ} 54^{\prime} \mathrm{N} \\
11^{\circ} 53^{\prime} \mathrm{E}\end{array}$ & Prede & $\begin{array}{l}\text { AOD }(11 \text { channels } 315-2200 \mathrm{~nm}) \text {, } \\
\text { Angström exponent }\end{array}$ \\
\hline Oslo & $\begin{array}{l}59^{\circ} 54^{\prime} \mathrm{N} \\
10^{\circ} 43^{\prime} \mathrm{E}\end{array}$ & Brewer & AOD $320 \mathrm{~nm}$ \\
\hline Sodankylä & $\begin{array}{l}67^{\circ} 22^{\prime} \mathrm{N} \\
26^{\circ} 37^{\prime} \mathrm{E}\end{array}$ & PFR & $\begin{array}{l}\text { AOD ( } 4 \text { channels } 368-862 \mathrm{~nm} \text { ), } \\
\text { Ångström exponent }\end{array}$ \\
\hline Toravere & $\begin{array}{l}58^{\circ} 15^{\prime} \mathrm{N} \\
26^{\circ} 27^{\prime} \mathrm{E}\end{array}$ & Cimel & $\begin{array}{l}\text { AOD ( }(7 \text { channels } 340-1020 \mathrm{~nm}) \text {, } \\
\text { Ångström exponent, single scat- } \\
\text { tering albedo }\end{array}$ \\
\hline
\end{tabular}

cloud screening was based on results from sky radiance analyses using the SKYRAD inversion scheme developed by Nakajima et al. (1996) for retrieving the aerosol optical properties.

Three of the sites, Minsk, ALOMAR and Ny-Ålesund, are also equipped with tropospheric lidars. The lidars in Minsk and at ALOMAR are both included in the European lidar network EARLINET (Pappalardo et al., 2006). The RayleighMie-Raman lidar of the National Academy of Sciences of Belarus, Minsk, is also a part of the CIS-LiNet (lidar network over Former Soviet Union countries) since 2004 (Chaikovsky et al., 2005). The Nd-YAG laser in Minsk emits radiation at 355,532 and $1064 \mathrm{~nm}$. The five channel receiving system detects intensity of lidar signals at the wavelengths 355 , $387\left(\mathrm{~N}_{2}\right.$ Raman) $1064 \mathrm{~nm}$, as well as co-polarized and crosspolarized components at the wavelength $532 \mathrm{~nm}$. The vertical resolution of the signal is $15 \mathrm{~m}$ and the duration of normal measuring series is $200 \mathrm{~s}$.

ALOMAR is located at Andenes at the Andøya island outside the Atlantic coast of Norway, about $300 \mathrm{~km}$ north of the Arctic Circle. This tropospheric lidar started its operation in July 2005 and is the only sub-Arctic/Arctic site in the EARLINET (Pappalardo et al., 2006). The RayleighMie-Raman lidar is based on a Nd-YAG laser, which emits radiation at 355, 532 and $1064 \mathrm{~nm}$. At present the system is equipped with five detector channels: $355,387 \mathrm{~nm}$ $\left(\mathrm{N}_{2}\right.$ Raman), $532 \mathrm{~nm}$ cross- and perpendicular polarized, and
$1064 \mathrm{~nm}$. The nominal range and temporal resolution is $7.5 \mathrm{~m}$ and $70 \mathrm{~s}$, respectively. For more details see Frioud et al. (2006).

A Micro-Pulse Lidar instrument was set up at Ny-Ålesund in 1998 and upgraded through the MPLNET project in 2002 (Welton et al., 2001). The National Institute of Polar Research, Japan operates the instrument at the AWIPEV station. The MPL employ a Nd/YLF laser, emitting radiation at wavelength of $523.5 \mathrm{~nm}$. The data are stored at one-minute time resolutions and $30 \mathrm{~m}$ vertical resolution. Details regarding on-site maintenance, calibration techniques, description of the algorithm used and data products are given in Campbell et al. (2002), and Shiobara et al. (2003, 2006).

Measurements of aerosol chemical composition and their size distribution at Zeppelin observatory are used to calculate the single scattering albedo and the DRF. The Zeppelin observatory is situated at the Zeppelin Mountain on the western coast of Svalbard (Norway). The Norwegian Institute for Polar Research maintains this observatory, while the Norwegian Institute for Air Research (NILU) is responsible for the research activities at the site. The major inorganic anions $\left(\mathrm{Cl}^{-}, \mathrm{NO}_{3}^{-}, \mathrm{SO}_{4}^{2-}\right)$ and cations $\left(\mathrm{Ca}^{2+}, \mathrm{Mg}^{2+} \mathrm{K}^{+}, \mathrm{Na}^{+}\right.$, $\mathrm{NH}_{4}^{+}$) were extracted by water from aerosol filter samples collected on a daily basis using an open filter face NILU filter holder loaded with a $47 \mathrm{~mm}$ Teflon filter (Zefluor, $2 \mu \mathrm{m}$ ). The cations and anions were quantified using ion chromatography. $\mathrm{NO}_{3}^{-}$and $\mathrm{NH}_{4}^{+}$are both subject to positive and negative 


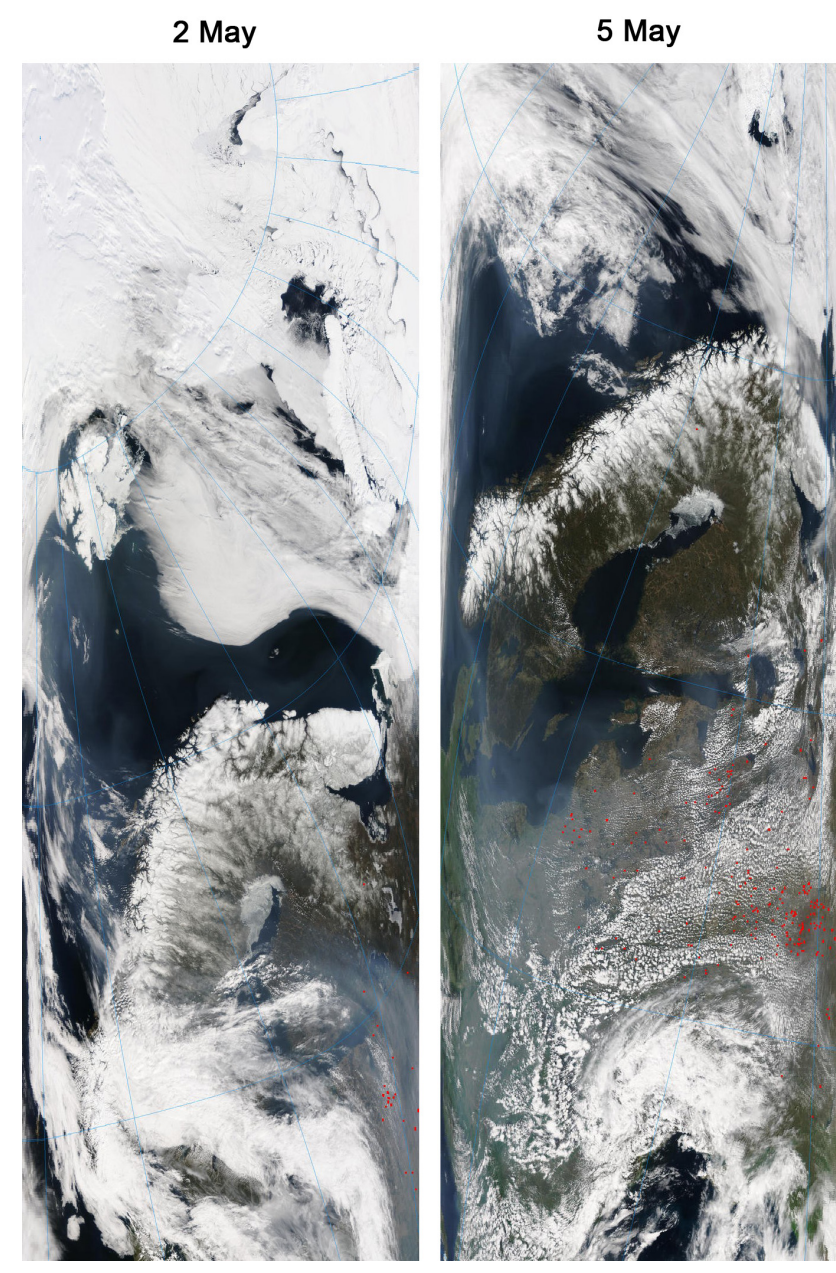

Fig. 2. The plume is clearly seen in the MODIS pictures of northeast Europe and Northern Scandinavia. The red dots in Eastern Europe indicate fires.

artefacts; here we use the sum of the particulate and the gas phase in our calculations. The ambient aerosol content of elemental carbon (EC) and organic carbon (OC) were obtained from aerosol filter samples, which were collected using a Leckel SEQ47/50, operating on a weekly basis. EC and OC were quantified by thermal-optical analysis, according to the NIOSH 5040 protocol (Birch and Cary, 1996). The aerosol chemical properties are described in Stohl et al. (2007). In the calculation of the single scattering albedo based on the chemical in situ measurements from Zeppelin we have used the chemical composition from Zeppelin as presented in Table 2 .
Table 2. Chemical composition at Zeppelin during 30 April-7 May 2006.

\begin{tabular}{ll}
\hline Component & $\begin{array}{l}\text { Concentration } \\
\left(\mu \mathrm{g} \mathrm{m}^{-3}\right)\end{array}$ \\
\hline Elemental carbonaceous matter & 0.26 \\
$(\mathrm{EM})(\mathrm{EM}=\mathrm{EC} \times 1.1)^{*}$ & \\
Organic carbon $(\mathrm{OC})$ & 3.53 \\
Organic matter $(\mathrm{OM}=\mathrm{OC} \times 1.8)^{* *}$ & 6.35 \\
$\mathrm{SO}_{4}^{2-}$ & 1.44 \\
$\mathrm{NO}_{3}^{-}$ & 0.90 \\
$\mathrm{NH}_{4}^{+}$ & 0.64 \\
\hline
\end{tabular}

* Kiss, et al. (2002)

* Turpin, et al. (2001)

\section{Aerosol optical properties in Northern Europe and the European Arctic during spring 2006}

\subsection{Satellite aerosol optical depth during spring 2006}

To perform a regional analysis and explore the evolution of the aerosol plume in time and space, we have used Moderate Resolution Imaging Spectroradiometer (MODIS) on board Terra and Aqua. We have studied the region $50-85^{\circ} \mathrm{N}$, and $0-40^{\circ} \mathrm{E}$, which includes the source area and the transport pathway of the plume into the Arctic. Figure 2 shows MODIS images at wavelengths in the visible region and how the smoke covers the northeast of Europe and the northern part of Scandinavia on two selected dates: 2 and 5 May. MODIS hot spot indicating the fires are represented by the red marks in the pictures. On 2 May, the smoke was transported across Finland, Sweden, traversing ALOMAR at the coast of Norway and up to Svalbard. On the 5 May a plume went south of Norway and north along the Norwegian coast to Svalbard in the Arctic.

In this section, we present the daily level 3 AOD at $550 \mathrm{~nm}$ retrieved from MODIS Collection Version 5 (Levy et al., 2007) to give a regional overview of the AOD during the smoke transport event. We have combined the data from Aqua and Terra ((MYD08_M3.005 and MOD08_M3.005). In the next section we present a more detailed analysis of the aerosol optical properties based on the ground-based observations made at the sites shown in Fig. 1.

In Polar Regions, the MODIS data coverage is low as satellite measurements of aerosol properties are difficult due to the conditions with high surface albedo, high cloud cover, large solar zenith angle, and thus a long path through the atmosphere. Further, the AOD retrievals are not performed under cloudy conditions or in regions with high surface albedo due to snow and ice surfaces. To increase the geographical data coverage we have combined the data from Terra and Aqua by including Aqua data when there are no data from 
Table 3. $\mathrm{AOD}_{\lambda=500 \mathrm{~nm}}$, Ångström exponent, $\alpha$, mean values over the specified period and data during the May 2006 smoke transport event. Typical values for Arctic haze are also included for the Arctic and sub-Arctic sites.

\begin{tabular}{llllllll}
\hline Site & \multicolumn{3}{c}{ May mean values $(1 \sigma)$} & \multicolumn{2}{c}{ Typical Arctic haze level } & \multicolumn{2}{c}{ May 2006 peak } \\
\hline & Period & AOD & $\alpha$ & AOD & $\alpha$ & AOD & $\alpha$ \\
\hline ALOMAR & 2007 & $0.09(0.03)$ & $1.65(0.5)$ & 0.13 & 1.65 & $0.45^{*}$ & - \\
Hornsund & 2005 & $0.08(0.03)$ & $0.95(0.21)$ & & & & \\
Ny-Ålesund** & $1992-1999$ & $0.07(0.02)$ & $1.82(0.38)$ & 0.13 & 1.88 & 0.68 & 1.97 \\
Sodankylä & 2005 & $0.05(0.01)$ & $1.58(0.14)$ & $* * *$ & $* * *$ & 0.87 & 1.93 \\
Toravere & 2005 & $0.10(0.04)$ & $1.34(0.18)$ & & Not relevant & 1.33 & 2.12 \\
Minsk & 2005 & $0.22(0.02)$ & $1.36(0.19$ & & & 1.52 & 1.92 \\
\hline
\end{tabular}

$*$ at $\lambda=320 \mathrm{~nm}$

$* *$ Herber et al. (2002), spring background

$* * *$ There are no typical Arctic haze values for Sodankylä as this was the first spring with AOD measurements at the site.

Terra available. The total data coverage in investigated geographical region during the period was $69 \%$.

Daily MODIS AOD at $550 \mathrm{~nm}$ is shown in Fig. 3 for the period 25 April-12 May. The Figure shows high AOD in Eastern Europe from 25 April, and how the plume developed and expanded during the period. The MODIS AOD values in the centre of the plume were in the range from 0.8 to well above 1 for the entire period. During the first two days the centre of the plume was located in the Eastern Europe influencing the AERONET sites in Toravere and Minsk. Two days later AOD values ranging from 0.6-1 can be seen above the Barents Sea, and close to Svalbard. At this time the plume was already influencing the sites at Zeppelin, $\mathrm{Ny}$ Ålesund and Hornsund. In the period 29 April-1 May, the main aerosol plume covered Eastern Europe, southern parts of Finland, Sweden, and northern part of Norway influencing the ground-based sites in Minsk, Toravere, and ALOMAR. During 2-4 May, the centre of the plume was shifted more towards Finland, western part of Russia and northern parts of Sweden covering the site in Sodankylä. During the period from 1-5 May, high AOD values were calculated in the Arctic region around Svalbard as well covering the sites at Zeppelin and Hornsund. On the 5 May particularly high AOD values were observed north of Svalbard with maximum values between 0.7-0.8. From 5-12 May AOD in the source region was gradually reduced and return to normal values from around 9 May in Eastern Europe. In this period the plume was visible from satellite pictures along the coast of Norway.

3.2 Optical properties of aerosols from ground based observations during spring 2006

\subsubsection{Spectral aerosol optical depth features}

The sun photometers located at the various sites included in this study (Fig. 1) allow monitoring of the smoke episode under clear sky conditions. They provide higher temporal resolution and accuracy than the satellite retrievals, although with limited spatial information.

As mentioned in the introduction, the AOD levels on 2 and 3 May constitute the record at Svalbard after more than 15 years of measurements. Table 3 provides a summary of mean AOD for May 2005 (except for ALOMAR where the year is 2007) and the Ångström exponent for the Arctic sites, compared to typical values during Arctic haze events, and the peak values during the extreme spring 2006 episode (Herber et al., 2002; Toledano et al., 2006; Aaltonen et al., 2006). The Ångström exponent, $\alpha$, represents the wavelength dependence of the aerosol extinction coefficient $b_{\text {ext }}$ and is defined as $b_{\text {ext }}=\lambda^{\alpha}$ where $\lambda$ is the wavelength. $\alpha$ provides information about the size of the aerosols, and larger values of $\alpha$ imply a relatively high ratio of small particles. In this work the calculation of $\alpha$ is performed using to following relationship $\mathrm{AOD}_{\lambda}=\operatorname{AOD}_{\lambda_{0}}\left(\lambda / \lambda_{0}\right)^{-\alpha}$ employing the commonly used wavelength pairs. In Table 3 the AOD mean levels for May 2005 for the Arctic sites are higher than the Arctic background values reported by (Tomasi et al., 2007). In general the AOD increases by 30-100\% during typical spring haze compared to the corresponding background levels. The smoke episode in May 2006 is exceptionally intense, with an AOD 3-4 times higher than in typical Arctic haze periods.

The time series of AOD at the Scandinavian sites are presented in Fig. 4a and b. The AOD is shown in the left panel whereas the right panel shows the Ångström exponent $(\alpha)$. The episode over Scandinavia is clearly evident in the figures. On 2 and 3 May there are peaks in the AOD at all the Arctic sites with the following maximum levels of $\mathrm{AOD}_{\lambda}=500$ of 0.68 in Ny-Ålesund, 0.52 in Hornsund, 0.87 in Sodankylä, and $\mathrm{AOD}_{\lambda=320}$ of 0.45 at ALOMAR. 2 May was the day with the maximum level in Ny-Ålesund and Hornsund while 3 May was the day with the maximum level in Sodankylä. The first intense AOD peak measured at ALOMAR was on 30 April, the second was on 2 May, at the same level. The weather in Sodankylä permits a more continuous monitoring 

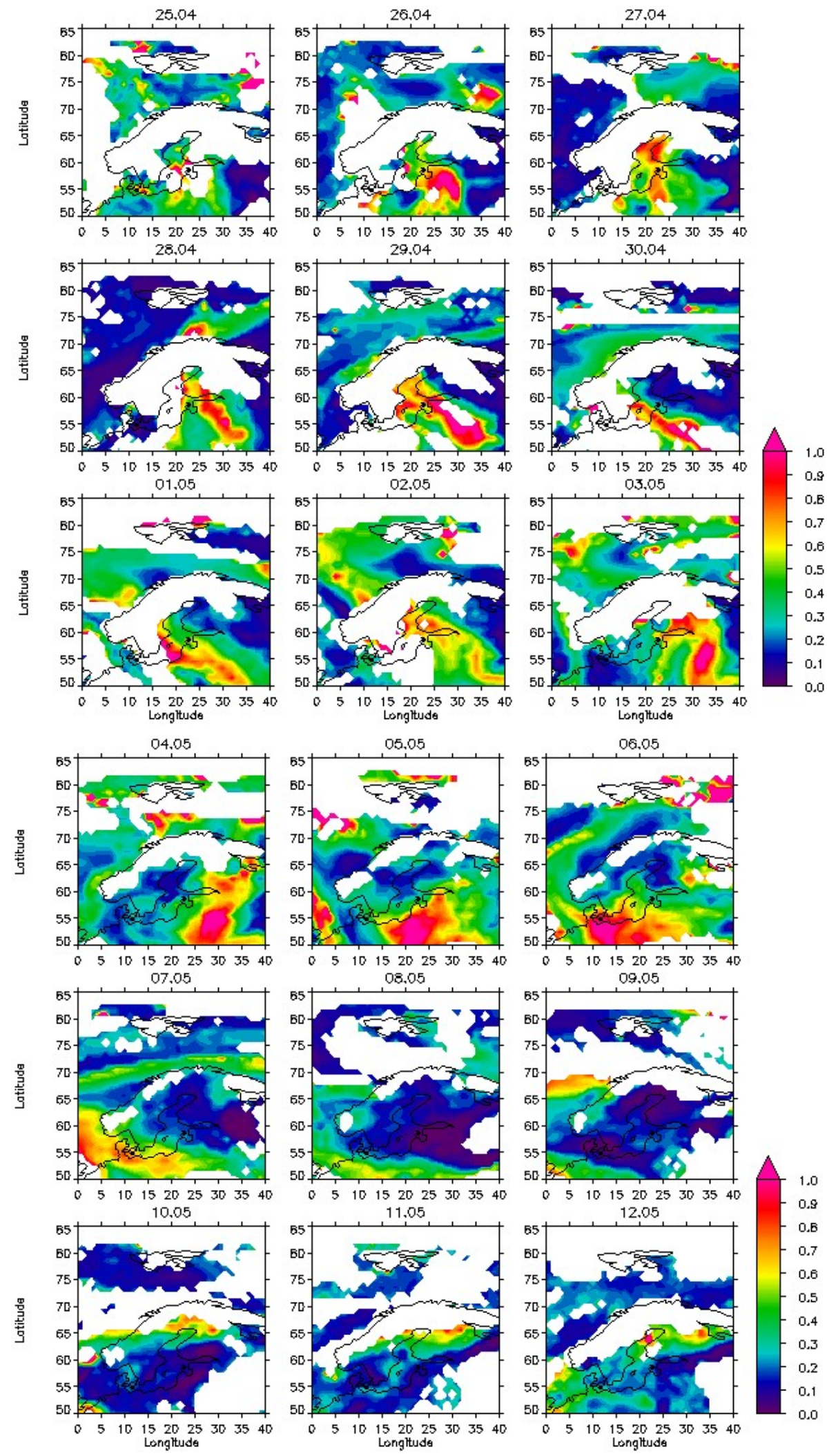

Fig. 3. Aerosol optical depth at $550 \mathrm{~nm}$ for the period 25 April-12 May 2006 from the MODIS Collection Version 5. The data from Aqua and Terra is combined in the plots. 


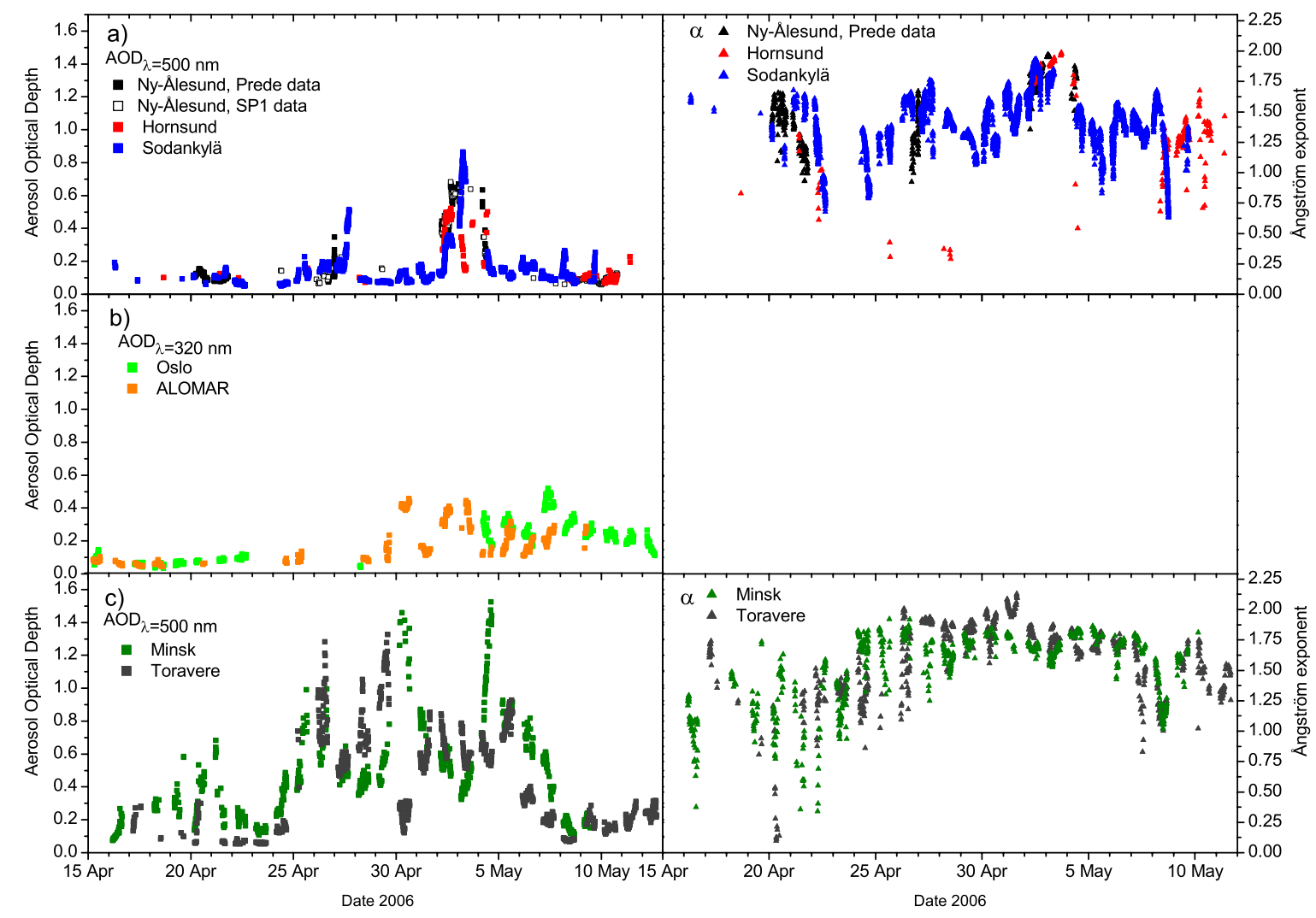

Fig. 4. Left column: Aerosol optical depth for (a) Ny-Ålesund, Hornsund and, Sodankylä, (b) ALOMAR and Oslo (c) Minsk, Toravere. Right column: Ångström exponent for Hornsund and, Sodankylä in the upper panel and for Toravere and Minsk in the lower panel.

of the episode. For this site we can see the first elevated AOD peak on 27 April, and a second peak on 2 May. The third main peak was observed on 3 May and reached the maximum value of 0.87 . All these main peaks are also observed in Ny-Ålesund.

The Brewer instrument maps the episode affecting Oslo. Unfortunately there are almost no data available from 22 April to 4 May due to cloudy conditions, so it is not possible to recognize the first plume, taking place at the end of April. From 4 May, the AOD measurements indicated that the aerosol loading was high. After the peak on 7 May $\left(\mathrm{AOD}_{\lambda=320}=0.52\right)$ the AOD decreased slowly due to the stable weather and atmospheric conditions, and the background level was not reached until 14 May.

The Ångström exponents shown in Fig. 4 were high, with values in the range from 1.5-2 for the days when the episode was most intense. In Sodankylä, the daily mean $\alpha$ was 1.51 on 27 April, 1.72 on 2 May and 1.88 on 3 May, whereas more typical values were recorded after the event (1.01 on 10 May). In Hornsund values of 1.77 on 2 May and 1.92 on 3 May were recorded. The time evolution of $\alpha$ in Sodankylä shows an increase during the days when the episode was intense (1.53 on 27 April and 1.87 on 3 May) compared to the less turbid days. The increase in $\alpha$ follows a similar pattern as the AOD, with two periods of enhanced levels centred on 27 of April and 2 May (Fig. 4a). This shows that the plume produced an increase in the slope of the spectral AOD, demonstrating that the fine mode fraction of the aerosols is increased. This implies that the transported smoke aerosols were predominantly small, which is in agreement with the results of the SAFARI campaign and literature on biomass burning aerosols (Eck et al., 1999; O'Neill et al., 2002; Reid et al., 2005). The observed elevation of the Ångström exponent for aerosols from fires that are transported into the Polar region is in agreement with the characterisation of Polar aerosols presented by Tomasi et al. (2007) and the results at Ny-Ålesund for this particular episode reported by Treffeisen et al. (2007).

Data from the Arctic and sub-Arctic locations are similar to the data obtained in the aerosol source region. This is shown in Fig. 4c) by means of the AOD and $\alpha$ measured at the AERONET sites in Toravere and Minsk. The first remark is related to the intensity of the episode. The AOD levels in Estonia and Belarus were as high as 1.33 in Toravere (29 April) and 1.52 in Minsk (4 May). The May 2005 mean AOD for the sites are 0.10 and 0.22 , respectively, whereas the mean Ångström exponent is 1.34 and 1.36 (Table 3). However, for the period 15 April-15 May 2006, the mean AOD (500 nm) 
Table 4. Summary of the aerosol size distributions and single scattering albedo for the inversions realized under $\mathrm{AOD}_{440 \mathrm{~nm}}>0.5$ and SZA $>50^{\circ}$ : mean Median Radius $(\mu \mathrm{m})$ and geometric standard deviation $(\sigma)$, SSA and number of inversion data $(\mathrm{N})$ available. The number of inversions for $\mathrm{AOD}_{440 \mathrm{~nm}}>0.5, \mathrm{SZA}>50^{\circ}$ and $>21$ symmetrical angles are in brackets.

\begin{tabular}{lllll}
\hline $\begin{array}{l}\text { Site } \\
\text { Parameter* }\end{array}$ & Minsk & Toravere & Hornsund & Ny-Ålesund \\
\hline$r_{v 1}$ & $0.160\left(2 \times 10^{-3}\right)$ & $0.159\left(2 \times 10^{-3}\right)$ & $0.122\left(4 \times 10^{-3}\right)$ & ND \\
$\sigma_{1}$ & $0.420\left(1 \times 10^{-2}\right)$ & $0.33\left(1 \times 10^{-2}\right)$ & $0.37\left(3 \times 10^{-2}\right)$ & ND \\
Volume fraction, mode 1 & $0.040\left(2 \times 10^{-4}\right)$ & $0.060\left(1 \times 10^{-4}\right)$ & $0.54\left(7 \times 10^{-4}\right)$ & \\
$r_{v 2}$ & $1.96\left(3 \times 10^{-2}\right)$ & $1.45\left(1.5 \times 10^{-1}\right)$ & $1.80\left(7.5 \times 10^{-1}\right)$ & ND \\
$\sigma 2$ & $0.487\left(9 \times 10^{-2}\right)$ & $0.34\left(8 \times 10^{-2}\right)$ & $0.32\left(4 \times 10^{-2}\right)$ & ND \\
Volume fraction, mode 2 & $0.079\left(8 \times 10^{-4}\right)$ & $0.08\left(2 \times 10^{-2}\right)$ & $0.45\left(9 \times 10^{-3}\right)$ & \\
$r_{v 3}$ & $7.19\left(1.7 \times 10^{-1}\right)$ & $5.7\left(2 \times 10^{-1}\right)$ & - & - \\
$\sigma_{3}$ & $0.425\left(2 \times 10^{-2}\right)$ & $0.43\left(4 \times 10^{-2}\right)$ & - & - \\
Volume fraction, mode 3 & $0.881\left(8 \times 10^{-2}\right)$ & $0.86\left(8 \times 10^{-2}\right)$ & - & - \\
SSA $_{440 \mathrm{~nm}}$ & $0.917\left(2 \times 10^{-2}\right)$ & $0.92\left(2 \times 10^{-2}\right)$ & $0.984\left(4 \times 10^{-3}\right)$ & $0.98^{* *}$ \\
SSA $_{1020 \mathrm{~nm}}$ & $0.811\left(4 \times 10^{-2}\right)$ & $0.88\left(4 \times 10^{-2}\right)$ & $0.962\left(9 \times 10^{-3}\right)$ & $0.88-0.93 * *$ \\
N data & $114(63)$ & $189(41)$ & $44(7)$ & - \\
\hline
\end{tabular}

$*$ Standard errors are given in brackets.

** Retrieved from in situ measurements at the Zeppelin observatory. The range is caused by variations in the relative humidity during the period.

is 0.41 in Toravere and 0.44 in Minsk. For the corresponding $\alpha$ the means are 1.56 and 1.50 , respectively. The episode is thus characterized by high AOD, with peaks almost one order of magnitude higher than the normal values, together with an increase in the Ångström exponent up to 1.6-2.1 on days with enhanced aerosol loadings.

The intensity of the episode changes with time, and a similar pattern for AOD in Toravere and Minsk is evident (except for 30 April). The two time series are in good agreement, indicating that aerosol plumes with similar characteristics are affecting both sites for almost one month. The agreement in the $\alpha$ parameter is also remarkable. The uncertainty in the Ångström exponent decreases when AOD increases. For the AOD measured in this period, the Ångström exponent is reliable, with an absolute uncertainty below 0.1 , considering the nominal AERONET absolute uncertainty for the AOD (0.01-0.02) (Toledano, 2005).

\subsubsection{Size distributions and single scattering albedo}

The sky radiance measurements obtained with the Cimel sun photometer permit the retrieval of particle size distribution and complex refractive index (Dubovik and King, 2000). Hence the optical parameters essential for the aerosol characterization, such as the single scattering albedo and the asymmetry parameter can be obtained. As indicated in Dubovik et al. (2002), the retrieval of the particle volume size distribution is adequate in practically all situations. However, the retrieved values of SSA and the complex refractive index must be utilized only from the retrievals obtained with high aerosol loading $\left(\mathrm{AOD}_{\lambda=440}>0.5\right)$ and for solar zenith angle $\mathrm{SZA}>50^{\circ}$. For the three AERONET sites analysed, Hornsund, Minsk and Toravere, the inversion products are available. The aerosols radii, geometric standard deviations and volume fractions for each mode is given in Table 4 based on the inversions in the period 15 April-15 May. The single scattering albedo at $440 \mathrm{~nm}$ and $1020 \mathrm{~nm}$ is also included based on inversions retrieved under the restricted conditions during the event. The number of restricted inversions is given in parenthesis.

The volume size distributions for Minsk, Toravere and Hornsund at selected dates and times are presented in the right panel of Fig. 5a, b and c, respectively. The left panels show the average volume size distribution based on all the available distributions from the smoke episode as a black curve. The red curve is a reference volume size distribution representing a spring situation with typical AOD values.

The average median radii for the fine mode in Toravere and Minsk are $0.16 \mu \mathrm{m}$, hence significantly larger than $0.12 \mu \mathrm{m}$ in Hornsund. This is also the case with the coarse modes. However, the main difference between the size distributions for the sites close to the aerosol source region compared to Hornsund is the mode centred from 5-7 $\mu \mathrm{m}$, which is not present at Hornsund. Compared with background size distributions, both the fine and the coarse mode concentrations are approximately 10 times larger during the event in Minsk and Toravere. This is similar to the observed increase in the AOD during the smoke episode. Hence this indicates that both fine and coarse aerosols are emitted during the fires, or are produced by dynamic processes in the fresh smoke. However, at Hornsund the fine mode concentration during 

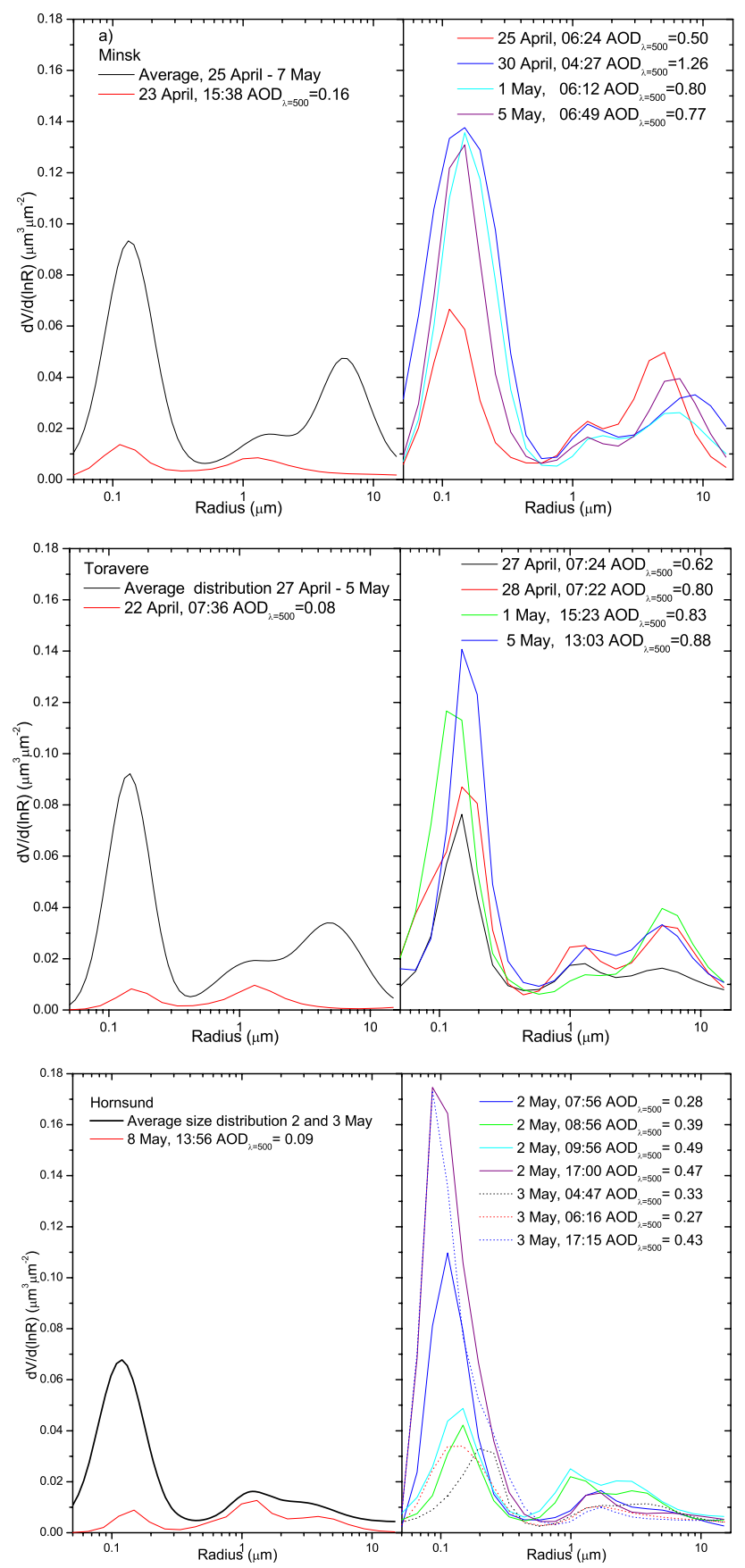

Fig. 5. Volume aerosol size distributions during the smoke transport event: (a) Minsk, (b) Toravere, (c) Hornsund. Right panel: Average distribution of the most intense period together with typical distribution. Right panel: Selected distributions during the period. AOD is given at $500 \mathrm{~nm}$. The red curve is a reference volume size distribution representing a spring situation with typical AOD values.

the most intense days is 10 times higher than the reference day shown, whereas the coarse mode only increases by a factor of 1.5-2. The coarse aerosols observed close to the

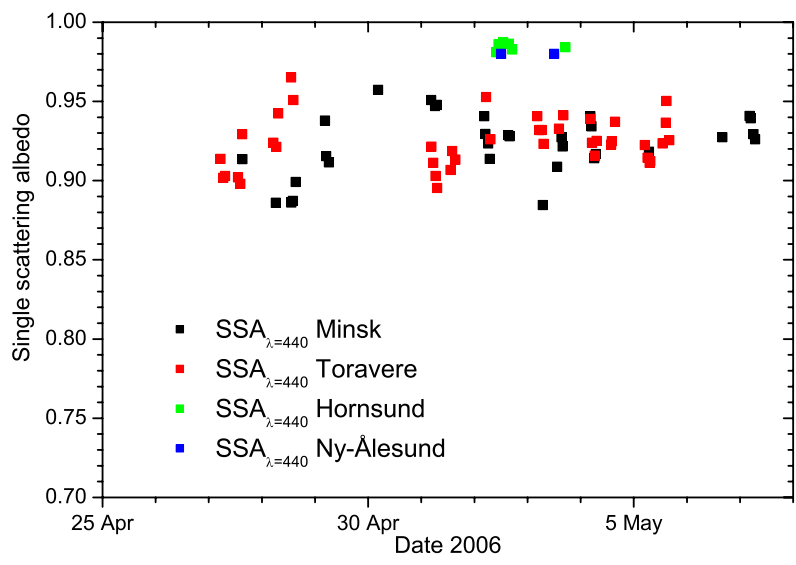

Fig. 6. Column single scattering albedo (SSA) retrieved from Cimel photometer data at Hornsund, Toravere and Minsk. For Ny-Ålesund the SSA is based on in situ measurements from the Zeppelin observatory.

source are likely deposited during the transport to Svalbard, while smaller aerosols have longer atmospheric residence times and followed the plume into the Arctic region.

On 2 May and 3 May 17:00 UTC both days, the fine mode peak of the volume size distribution in Hornsund (in Fig. c) are particularly intense compared to results earlier the respective days. According to Dubovik et al. (2002) errors up to $50 \%$ in the surface albedo do not have relevant impact on the calculations of the aerosol size distribution. However, due to the special conditions in the Arctic region we have examined this further. We performed a set of simulations of the sky radiance using the UVSPEC radiative transfer model in order to estimate spectral diffuse down-welling global irradiance for different AOD, sun elevation and surface albedos. The simulations indicated that for $\mathrm{AOD}_{\lambda=500}=0.5, \mathrm{SZA}=60^{\circ}$ and high surface albedo (snow) the diffuse irradiance increased by $45 \%$ at $440 \mathrm{~nm}$ compared to the same simulation for low surface albedo (water). For longer wavelengths, the increase is less $(22 \%$ at $1020 \mathrm{~nm})$. The effect is smaller as SZA increases (34\% of increased diffuse irradiance at $440 \mathrm{~nm}$ and $13 \%$ at $1020 \mathrm{~nm}$ for $\mathrm{SZA}=75^{\circ}$ ). This could explain the differences in the size distributions retrieved in Hornsund at large SZA $\left(75^{\circ}\right)$ compared to the observations around noon $\left(\mathrm{SZA}=61^{\circ}\right)$ on 2 May.

Regarding the study of biomass burning aerosols in Dubovik et al. (2002) their results indicate that typical single scattering albedo are ranging from $0.90-0.94$ at $440 \mathrm{~nm}$ (Eck et al., 1999; Dubovik et al., 2002). The values are expected to be somewhat lower at higher wavelengths. The SSA for Hornsund, Minsk and Toravere from the AERONET inversions are shown in Fig. 6 and the mean SSA is presented in Table 4 for the period 15 April-15 May together with their standard deviations. The mean SSA is 0.92 for Minsk and Toravere both with $\sigma=0.02$, and 0.98 for Hornsund with 
$\sigma=0.004$. In all cases SSA decreases with wavelength, with a mean of $0.81,0.88$ and 0.96 at $1020 \mathrm{~nm}$ at the different locations, respectively. The SSA at the Zeppelin observatory in Ny-Ålesund is calculated with Mie theory based on the chemical composition described in Sect. 2 with the average size distribution as described above. Hygroscopic growth is taken into account in the Mie calculations and relative humidity data are taken from ECMWF reanalysis data for the actual time period. The hygroscopic growth is taken into account for sulphate, nitrate, organic carbon, and sea salt aerosols according to Myhre et al. (2007). At the 2 May the SSA is calculated to 0.98 (range between $0.980-0.982$ due to variations in $\mathrm{RH}$ ) and for 3 May the SSA range between 0.974 and 0.981 at $440 \mathrm{~nm}$. At $1020 \mathrm{~nm}$ the calculated SSA is lower in accordance with the observations (modelled range between 0.880 and 0.928 ). Importantly, the calculated SSA is consistent with the retrieved SSA from the AERONET inversion in the Arctic region.

It is apparent that the SSA increases with the distance from the source. This is in accordance with results from agricultural fires in southern Africa (Abel et al., 2003). This increase in SSA implies that the aging and transport of the aerosols from the plume and towards the Arctic region reduce the aerosol absorption, whereas the scattering processes become more dominant. It might be explained by the deposition of the large aerosols during the transport. The large amount of coarse aerosols near the source (shown in Fig. 5) most likely contains a fraction of absorbing aerosols. If these larger aerosols are deposited during the transport to the Arctic, the total aerosol absorption will be reduced. The chemical composition measured at Zeppelin resulted in high SSA and supports this explanation. Approximately $60 \%$ of the characterised aerosol chemical composition at Zeppelin was organic matter. This is remarkably high compared to a more typical situation (5-10\%) (Stohl et al., 2007). Hence the relative contribution of the absorbing $\mathrm{BC}$ was small, even if the measured concentration was high. The common organic and inorganic components emitted from biomass burning are believed to have low absorption in the UV and visible region (Schkolnik et al., 2007; Myhre and Nielsen, 2004) thus scattering dominates the interaction with radiation leading to the high SSA in this region. The influence and variations in the relative humidity is also relevant. The relative humidity is much lower in Minsk and Toravere than in Hornsund and NyÅlesund. Sensitivity calculations show that employing the relative humidity observed in Minsk and Toravere, reduces the SSA at Ny-Ålesund to values in the range of 0.95-0.96. The increase of SSA can also be a result of condensation and/or formation of secondary organic aerosols (SOA) (Abel et al., 2003). An increase in the water content of the aerosols or an increase of SOA, will both change the relative fraction of scattering and absorbing aerosol components towards a higher fraction of scattering components. Thus this will both result in an increase of SSA. Lack of chemical composition of the aerosols close to the source makes it difficult to quantify the different contributions to the observed changes in the optical properties and further explain the observations. A combination of different processes is the most plausible explanation.

\subsubsection{Comparison of ground based AOD and MODIS AOD observations}

The AOD from MODIS aboard both the Terra and Aqua satellites is used in the radiative forcing calculations in Sect. 4. Thus a comparison of these data and the available ground based AOD at the different locations is required. In the comparison we have used area average time series of the MODIS Atmosphere Daily Global Product. We have extracted $1^{\circ} \times 1^{\circ}$ grid averaged MODIS data with the stations as the centre of the grids. Sodankylä is one exception. Due to low data coverage during the event we decided to use $3^{\circ} \times 3^{\circ}$ grid averaged MODIS data when there are no data available above the site. We have compared the data to MODIS AOD extracted from $1^{\circ} \times 1^{\circ}$-grid when possible and the results were satisfactory.

The results of the analysis of the time evolution of the episode are shown in Fig. 7. The Figure shows the MODIS $\mathrm{AOD}_{\lambda=550}$ from the daily overpasses of Aqua and Terra as the red and blue curves respectively in all panels. The satellite data are compared to the available ground-based data in the period 15 April-12 May 2006. Despite the differences in the time resolution the results are in good agreement. The correlation coefficients are higher than 0.97 expect for Sodankylä where the correlation is 0.94. Yet, there are some peaks not captured by the MODIS data, these can be explained by the higher temporal resolution of the groundbased data. Further, the MODIS data is slightly lower than the ground based data for Minsk. This is expected as the ground-based data are for $500 \mathrm{~nm}$.

Regarding Sodankylä, Hornsund and Ny-Ålesund, only the peak value observed 8 May at Hornsund is not captured by the satellite measurements. However, this peak is not detected at $\mathrm{Ny}-\AA ̊$ Alesund and it could be due to high cirrus.

AOD obtained from the Brewer instruments in Oslo and at ALOMAR are shown in the two middle panels. The AOD from the Brewers are for $\lambda=320 \mathrm{~nm}$, which should result in higher AOD than for the MODIS data. Accordingly, the figures demonstrate that there are significant deviations in the absolute values of the AOD from the Brewers and from MODIS. AOD achieved from Brewer measurements is a relatively new method and it is connected with large uncertainty as it is highly influenced by the neutral density filter spectral transmittance (Cheymol et al., 2006). However, the purpose of the comparison between the Brewer AOD and the MODIS AOD is rather to manifest the time evolution of the AOD in Oslo and at Andenes. The results from ALOMAR and Oslo in Fig. 7 clearly show that the elevated AOD levels detected by MODIS and obtained from the Brewers are analogous, and that the time series are parallel. Thus the transport of 


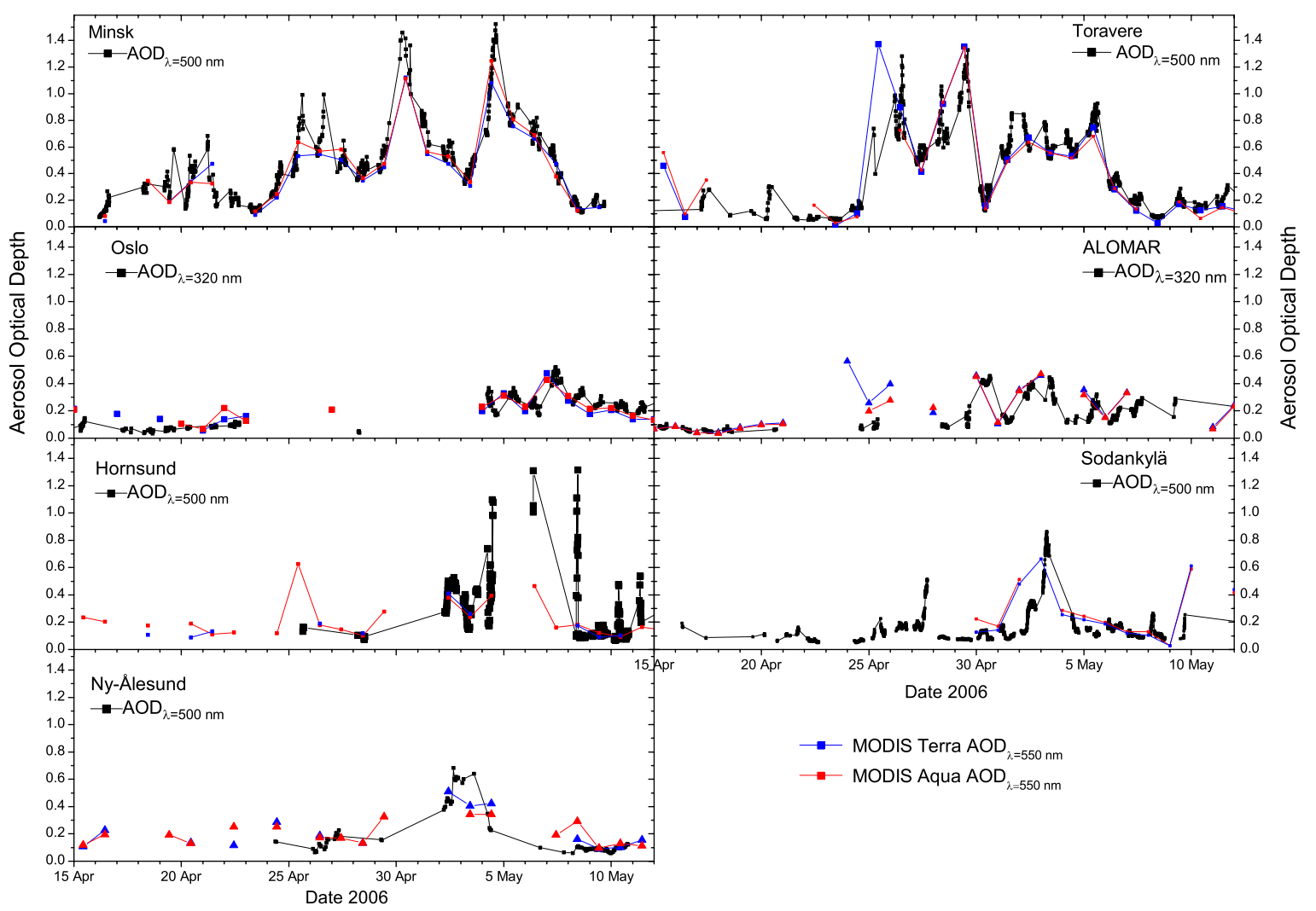

Fig. 7. Comparison of $1^{\circ} \times 1^{\circ}$ grid averaged MODIS AOD and AOD from the ground based stations in the period 15 April-15 May 2006 . For Sodankylä we have used $3^{\circ} \times 3^{\circ}$ grid averaged MODIS data when there are no data available above the site. The MODIS AOD from Aqua and Terra is the red and blue curves respectively in all panels.

the aerosol plume into the Arctic region is clearly evident in both datasets and the AODs from the Brewer measurements justify the use of the satellite data in the calculation of the radiative forcing of the episode.

3.3 Profiles of optical properties of aerosols from ground based observations during spring 2006

The development of the vertical distribution of the aerosol layer has been studied by tropospheric lidar measurements at three sites: Ny-Ålesund, ALOMAR (Andenes), and Minsk. The lidar at the latter site is located close to the source region. The corresponding profiles of the aerosol backscatter coefficients (ABC) are shown in Fig. 8.

For a detailed description about the transport and meteorological development during the episode see Stohl et al. (2007) and Treffeisen et al. (2007). Based on NOAA's Hysplit model back-trajectories the airflow towards Minsk changes from southward (24 April) to more westward (27 April) and west/north westward directions in beginning of May. On 24 April the aerosol plume from the fires filled the boundary layer in Minsk up to $1.875 \mathrm{~km}$ with an average backscatter coefficient of about $1.6 \times 10^{-6} \mathrm{~m}^{-1} \mathrm{sr}^{-1}$.
On 27 April the aerosol load increases to an average of $3.8 \times 10^{-6} \mathrm{~m}^{-1} \mathrm{sr}^{-1}$ below $1.905 \mathrm{~km}$. The maximum layer altitude increased to $3.045 \mathrm{~km}$ and $2.955 \mathrm{~km}$ in the beginning of May, with an average ABC of about $6.8 \times 10^{-6} \mathrm{~m}^{-1} \mathrm{sr}^{-1}$ and $2.8 \times 10^{-6} \mathrm{~m}^{-1} \mathrm{sr}^{-1}$ on 3 and 4 May, respectively. Such high values are comparable to high aerosol loadings occurring above Minsk in the summer during easterly and southerly air flow, when air masses are brought towards the station from the Ukraine and Black Sea region (Wandinger et al., 2004).

As observed by MODIS and the Brewer instrument at ALOMAR the plume reached the European Sub-Arctic region around 29 April. The ABC profiles from 25 April are characteristic for background aerosol load when air masses arrive at the site from south/westerly directions. On 1 May, ALOMAR is clearly influenced by the polluted air masses from the Eastern Europe with subsiding air masses coming from the south/east. The resulting ABC profile shows a maximum of about $1.6 \times 10^{-6} \mathrm{~m}^{-1} \mathrm{sr}^{-1}$ around $2 \mathrm{~km}$ altitude and a top layer altitude of $\sim 2.5 \mathrm{~km}$. During the next few days the pollution reaching the station continue to increase, and the maximum of the $\mathrm{ABC}$ profile doubled at 
3 May to $\sim 3.2 \times 10^{-6} \mathrm{~m}^{-1} \mathrm{sr}^{-1}$ around $1.5 \mathrm{~km}$, and the top layer altitude increased to $2.8 \mathrm{~km}$. The highest $\mathrm{ABC}$ values at ALOMAR was $3.5 \times 10^{-6} \mathrm{~m}^{-1} \mathrm{sr}^{-1}$ around $2 \mathrm{~km}$ with a top layer altitude at $\sim 3.1 \mathrm{~km}$. This was measured 5 May in the evening. On 6 May the air masses were coming from south/easterly direction bringing clear air, and the ABC profile measured by the lidar indicated clean background conditions. In the evening the same day again a higher aerosol load was observed, comparable to the layer seen on 1 May. Also on 7 May we find enhanced aerosol loading at this site.

In Ny-Ålesund the lidar profiles showed enhanced ABC values on 27 April. A maximum aerosol backscatter coefficient of $2.5 \times 10^{-6} \mathrm{~m}^{-1} \mathrm{sr}^{-1}$ at $\sim 1.5 \mathrm{~km}$ was measured on 2 May. Further, enhanced $\mathrm{ABC}$ values can be found up to about $4 \mathrm{~km}$ at that time at this Arctic site. However, the main aerosol layer is located below $2 \mathrm{~km}$, which is about one kilometre lower than the top of the plume observed in Minsk. During the second part of 3 May and the first part of 4 May, a denser aerosol layer was observed aloft. While on 2 May back-trajectories between 1 and $4 \mathrm{~km}$ altitude show a downsloping trend, on 3 May only the $1 \mathrm{~km}$ altitude backtrajectory shows subsidence, while above $2 \mathrm{~km}$ a lifting of the air masses was observed. Due to the smoke episode the layer averaged aerosol-to-backscatter coefficient increased from $58 \pm 2 \mathrm{sr}$ (20-21 April) to about $67 \pm 8 \mathrm{sr}$ (2 May) and the spectral Ångström coefficient increased from $1.4 \pm 0.1$ to $1.7 \pm 0.1$. This is consistent with the results presented in Sect. 3.2.1; polluted air with a pronounced contribution of aerosols in the accumulation mode (see Fig. 5).

\section{Direct radiative forcing of the May 2006 event}

Atmospheric aerosols are shown by observations alone or in combinations with model studies to have a global radiative impact. Further, there may be strong local effects in regions with high aerosol loadings (Haywood et al., 2003; Haywood et al., 1999; Kaufman et al., 2002; Myhre et al., 2007; Myhre et al., 2003a, b; Yu et al., 2006). The radiative effect of aerosols in the Arctic may differ from other regions due to the high surface albedo of snow and ice and during the summer period due to the high solar zenith angle that strengthen the radiative effect of scattering aerosols (Haywood and Shine, 1997; Myhre and Stordal, 2001). In the present study we have modelled the top of the atmosphere (TOA) short wave direct radiative effect of the aerosols using a multi-stream radiative transfer model (Myhre et al., 2007; 2003a) with the aerosols' chemical composition as described in Sect.2, the average volume size distribution described in Sect. 3.2.2, vertical profile of the aerosols based on the lidar observations in Sect. 3.3, and AOD from MODIS collection 5 data. Table 1 gives a summary of various data products available from the different sites. Data for clouds and relative humidity are taken from ECMWF reanalysis for the actual time period. Three-dimensional cloud fields from
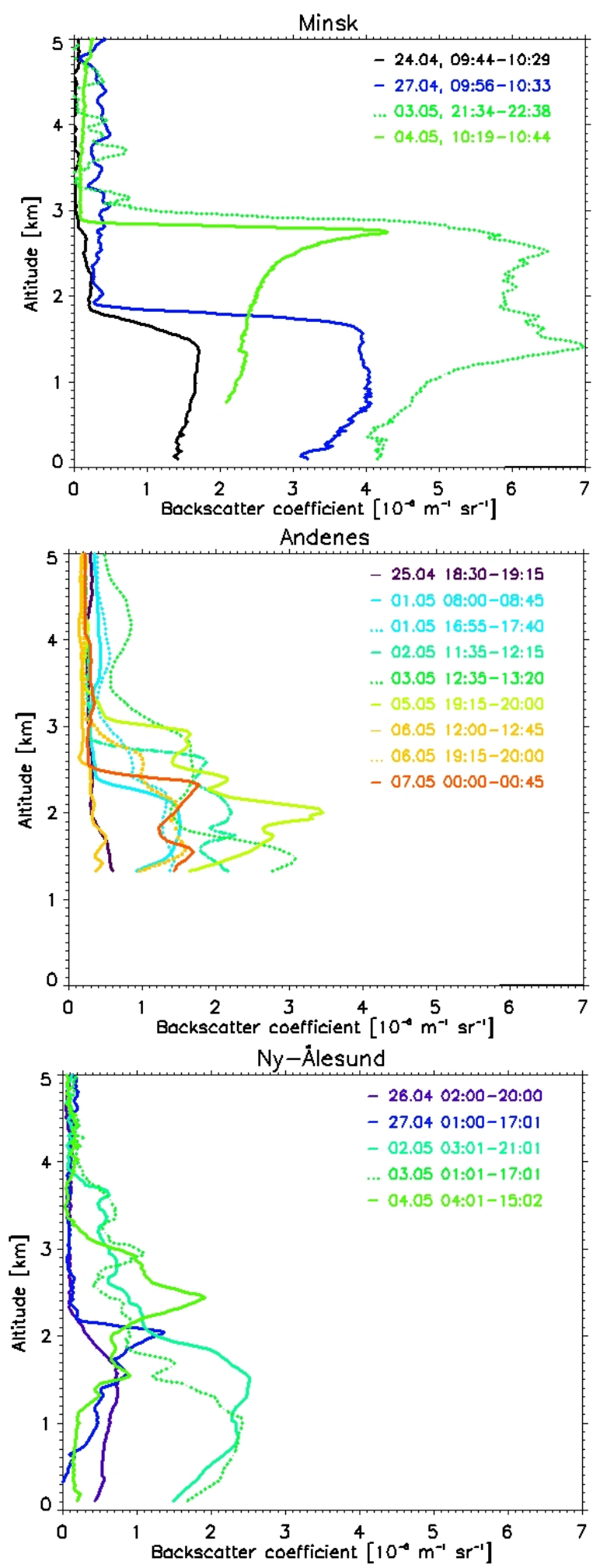

Fig. 8. Height profiles of backscatter coefficients of aerosols from ground based observations at the sites in Minsk, Andenes (ALOMAR), and Ny-Ålesund during spring 2006. 

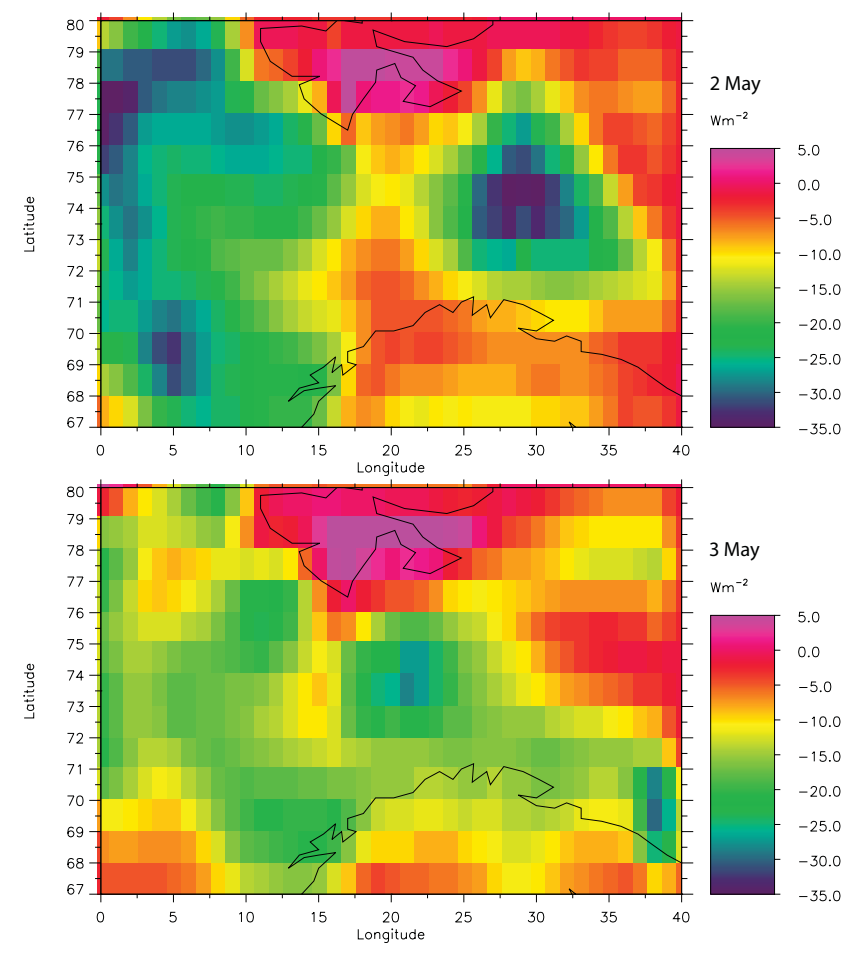

Fig. 9. Radiative forcing of the episode on 2 and 3 May relative to an aerosol situation in the spring with $\mathrm{AOD}=0.05$.

ECMWF with cloud fraction, cloud liquid water content and ice water content are used in the calculation of an all-sky radiative forcing. For the vertical profiles of the aerosols the lidar observations are used. Since the aerosols transported to the Arctic during this event are confined to the lower troposphere, the aerosols do not normally overlay the clouds. The surface albedo data used in the radiative transfer simulations are spectrally resolved and vary with vegetation and ground characteristics (Myhre et al., 2003a). Snow and sea ice content are taken from ECMWF and are included in the calculations of the surface albedo. In our model we calculate the AOD based on observed chemical composition and ambient relative humidity. The hygroscopic growth is taken into account as described in Myhre et al. (2007) for sulphate, nitrate, organic carbon, and sea salt (see also Sect. 3.2.2). The chemical composition is constant for the studied region but the AOD will vary somewhat due to the ambient relative humidity. The measured chemical composition of the aerosols is a weekly averaged, thus the AOD calculated by the model is scaled with the daily AOD from MODIS to provide AOD for whole region representative for the pollution event. In regions with missing AOD from MODIS, we have used values from nearby grid points.

Short wave radiative forcing calculations are performed as a difference between the MODIS AOD for the smoke episode, and a corresponding background aerosol layer with equal optical properties with AOD of 0.05 . We have thus calculated daily mean TOA radiative forcing for all-sky condition (clouds included). The direct radiative forcing due to aerosols are dominated by the shortwave forcing since the longwave forcing is small except for mineral dust (Schulz et al., 2006; Reddy et al., 2005). Hence we have neglected the longwave forcing. Figure 9 shows regional cooling effects of the aerosols, between 30 and $40 \mathrm{~W} \mathrm{~m}^{-2}$, in daily average for 2 May in the regions with highest AOD. It is also a large region with values between -10 and $-30 \mathrm{~W} \mathrm{~m}^{-2}$. For the 2 May the MODIS data show high AOD in the Barents Sea north of Russia as well and remarkable low forcings are calculated, around $-35 \mathrm{~W} \mathrm{~m}^{-2}$. The values for 3 May, which is shown in the lower panel, are slightly weaker in accordance with the maximum AOD values. In comparison, an aerosol layer with the same column optical properties but a typical $\mathrm{AOD}$ value for the season, $\mathrm{AOD}=0.05$, will have maximum cooling effect around $5 \mathrm{~W} \mathrm{~m}^{-2}$. Over Svalbard the radiative forcing is positive due to a much higher surface albedo than in the rest of the studied region. North of $80^{\circ} \mathrm{N}$ there are no MODIS data but sensitivity simulations show positive radiative forcing in this region although of smaller magnitude than shown in Fig. 9. The forcings are typically of less than $5 \mathrm{~W} \mathrm{~m}^{-2}$ but could reach $20 \mathrm{~W} \mathrm{~m}^{-2}$ in some few cloudy regions. Quinn et al. (2007) calculated a positive radiative forcing for typical haze in the Arctic region. They based their simulations on observed SSA, which was lower than what was observed under this smoke transport event.

\section{Conclusions}

We have investigated the optical properties and distribution of the aerosols produced during the agricultural fires in Eastern Europe in spring 2006. Based on the transport analysis of Stohl et al. (2007) and the available MODIS data for the period we have selected 6 different sites all influenced by the smoke plume during its transport into the Arctic region. We present the AOD for all sites, and the Ångström exponent, the volume size distribution, single scattering albedo (SSA), and the vertical distribution of the aerosols when available. In addition, we have analysed the MODIS AOD for the region and time period and used all the collected data and information in regional radiative forcing calculations of this heavy smoke transport episode to the Arctic.

The single scattering albedo in Minsk and Toravere is exclusively based on the AERONET inversion products. However, for the two sites at Svalbard it is based on both AERONET products from Hornsund and in situ observations at Zeppelin, Ny-Ålesund. Close to the source the SSA are low, 0.92 (at $440 \mathrm{~nm}$ ) in both Minsk and Toravere. At Svalbard, the SSA is 0.98 (at $440 \mathrm{~nm}$ ) for both sites, hence there are consistency between the AERONET products and the calculations based on the in situ aerosol chemical composition with regard to the single scattering albedo. 
The direct effect of aerosols in the Arctic region require special attention as the region is characterized by short wave forcing both during day and night in the summer, and high surface albedo. In the radiative forcing calculations we have used AOD from the MODIS instrument on board Aqua and Terra. The uncertainty in the MODIS AOD is larger than elsewhere as satellite measurements of aerosol properties in the Polar Regions are difficult due to high surface albedo, large solar zenith angle, and long path through the atmosphere. We have compared the satellite retrieved AOD to the available ground based AOD observations to verify the use of MODIS AOD in the radiative forcing calculations. The results are convincing, as we find high agreement at all sites.

The radiative forcing of such an extreme smoke episode in the Arctic show that the aerosols have a strong cooling effect above the ocean, and a much weaker heating effect above the ice and snow covered area. In total the scattering and thus the atmospheric cooling will be the dominating process when the SSA is as high as in this pollution event. It has been proposed that increased haze events from more frequent forest fires in a warmer climate will enhance the Arctic warming (Law and Stohl, 2007). However, based on our analysis this is not obvious. A central topic regarding the future is the surface albedo and its expected change. The climate effect of the aerosols in this region is particularly sensitive to the surface albedo and the predicted change in the ice and snow cover as well as the deposition of dark aerosols on ice and snow, will reduce the warming effect of the absorbing aerosols.

Acknowledgements. We acknowledge the NASA Earth Observing System and Radiation Sciences Program, which funds the NASA Micro-Pulse Lidar Network. We thank R. Neuber who is responsible for all lidar measurements at AWIPEV and K. Marholdt for operating the MPL during the haze event. We acknowledge J. E. Kristjánsson, University of Oslo, and the Head of ALOMAR M. Gausa for the efforts in establishing and maintaining the tropospheric lidar at ALOMAR. We would like to thank the staff of ALOMAR for maintaining the facilities at the ALOMAR observatory, http://alomar.rocketrange.no/. We thank A. Dahlback, University of Oslo, for the Brewer measurements from Oslo. We also thank J. Ström at Stockholm University for providing us with the measured EC and OC data at the Zepplin observatory. We thank A. Herber, Alfred Wegner Institute, for providing us with the AOD values from AWIPEV, Ny-Ålesund for the period. Finally, the authors gratefully acknowledge the NOAA Air Resources Laboratory (ARL) for the provision of the HYSPLIT transport and dispersion model and/or READY website (http://www.arl.noaa.gov/ready.html) used in this publication.

Edited by: K. Carslaw

\section{References}

Aaltonen, V., Lihavainen, H., Kerminen, V. M., Ginzburg, M., Kulmala, M., and Viisanen, Y.: Three years of AOD measurements at three bipolar sites, in NOSA Aerosol Symposium Helsinki,
2006, Report series in aerosol science, no. 83, 17-20, Aerosolitutkimusseura, Yliopistopaino, 2006.

Abel, S. J., Haywood, J. M., Highwood, E. J. Li, J., and Buseck, P. R.: Evolution of biomass burning aerosol properties from an agricultural fire in southern Africa, Geophys. Res. Lett., 30(15), 1783, doi:10.1029/2003GL017342, 2003.

Bellouin, N., Boucher, O., Haywood, J., et al.: Global estimate of aerosol direct radiative forcing from satellite measurements, $\mathrm{Na}$ ture, 438, 7071, 1138-1141, 2005.

Birch, M. E. and Cary. R. A.: Elemental carbon-based method for monitoring occupational exposures to particulate diesel exhaust, Aerosol Sci. Tech., 25, 221-241, 1996.

Campbell, J. R., Hlavka, D. L., Welton, E. J., Flynn, C. J., Turner, D. D., Spinhirne, J. D., Scott, V. S., and Hwang, I. H.: Full-time eye-safe cloud and aerosol lidar observation at Atmospheric Radiation Measurement program sites: Instruments and data processing, J. Atmos. Ocean. Techn., 19(4), 431-442, 2002.

Campbell, J. R., Welton, E., J., Spinhirne, J. D., Ji, Q., Tsay, S. C., Piketh, S. J., Barenbrug, M., and Holben, B. N.: Micropulse lidar observations of tropospheric aerosols over northeastern South Africa during the ARREX and SAFARI 2000 dry season experiments, J. Geophys. Res., 108(D13), 8497, doi:10.1029/2002JD002563, 2003.

Chaikovsky A. P., Ivanov, A. P., Yu. S., Balin, Elnikov, A. V., Tulinov, G. F., Plusnin, I. I., Bukin, O. A., and Chen, B. B.: CISLiNet lidar network for monitoring aerosol and ozone: methodology and instrumentation, Atmos. Oceanic Opt., 18, 958-964, 2005.

Cheymol, A., De Backer, H., Josefsson, W., and Stübi, R.: Comparison and validation of the aerosol optical depth obtained with the Langley plot method in the UV-B from Brewer Ozone Spectrometer measurements, J. Geophys. Res., 111, D16202, doi:10.1029/2006JD007131, 2006.

Dubovik, O., Holben, B. N., Eck, T. F., Smirnov, A., Kaufman, Y. J., King, M. D., Tanre, D., and Slutsker I.: Variability of absorption and optical properties of key aerosol types observed in worldwide locations, J. Atmos. Sci., 59, 590-608, 2002.

Dubovik, O. and King, M.: A flexible inversion algorithm for retrieval of aerosol optical properties from sun and sky radiance measurements, J. Geophys. Res., 105(D16), 20 673-20 696, doi:10.1029/2000JD900282, 2000.

Dubovik, O., Smirnov, A., Holben, B. N., King, M. D., Kaufman, Y. J., Eck, T. F., and Slutsker, I.: Accuracy assessments of aerosol optical properties retrieved from AERONET sun and sky-radiance measurements, J. Geophys. Res., 105(D8), 97919806, doi:10.1029/2000JD900040, 2000.

Eck, T. F., Holben, B. N., Reid, J. S., Dubovik, O., Smirnov, A., O'Neill, N. T., Slutsker, I., and Kinne, S.: The wavelength dependence of the optical depth of biomass burning, urban and desert dust aerosols, J. Geophys. Res., 104(D24), 31 333-31 350, doi:10.1029/1999JD900923, 1999.

Frioud, M., Gausa, M., Baumgarten, G., Kristjansson, J. E., and Føre, I.: New tropospheric lidar system in operation at ALOMAR ( $\left.69^{\circ} \mathrm{N}, 16^{\circ} \mathrm{E}\right)$, in: C. Nagasawa, N. Sugimoto (Eds.), Reviewed and Revised Papers of the 23rd International Laser Radar Conference (ILRC), 24-28 July 2006, Nara, Japan, 179-182, 2006.

Gómez-Amo, J. L., Martínez-Lozano, J. A., Utrillas, M. P., Pedrós, R., and Estellés, V.: Column-integrated aerosol optical properties 
in Sodankylä (Finland) during the Solar Induced Fluorescence Experiment (SIFLEX-2002), J. Geophys. Res., 111, D05202, doi:10.1029/2005JD006051, 2006.

Hansen, J., Sato, M., and Ruedy, R.: Radiative forcing and climate response, J. Geophys. Res., 102(D6), 6831-6864, doi:10.1029/96JD03436, 1997.

Hansen, J. and Nazarenko, L.: Soot climate forcing via snow and ice albedos, Proceedings of the National Academy of Sciences of the United States of America, 101, 2, 423-428, 2004.

Harrison, L. and Michalsky, J.: Objective algorithms for the retrieval of optical depths from ground-based measurements, Appl. Optics, 33, 5126-5132, 1994.

Hatakka, J., Aalto, T., Aaltonen, V., Aurela, M., Hakola, H., Komppula, M., Laurila, T., Lihavainen, H., Paatero, J., Salminen, K., and Viisanen, Y.: Overview of the atmospheric research activities and results at Pallas GAW station, Boreal Environ. Res., 8, 365-383, 2003.

Haywood, J. M., Francis, P., Osborne, S., Glew, M., Loeb, N., et al.: Radiative properties and direct radiative effect of Saharan dust measured by the C-130 aircraft during SHADE: 1. Solar spectrum, J. Geophys. Res., 108(D18), 8471, doi:10.1029/2002JD002250, 2003.

Haywood, J. M., Ramaswamy, V., and Soden, B. J.: Tropospheric aerosol climate forcing in clear-sky satellite observations over the oceans, Science, 283(5406), 1299-1303, 1999.

Haywood, J. M. and Shine, K. P.: Multi-spectral calculations of the direct radiative forcing of tropospheric sulphate and soot aerosols using a column model, Q. J. Roy. Meteor. Soc., 123(543), 19071930, 1997.

Haywood, J. and Boucher, O.: Estimates of the direct and indirect radiative forcing due to tropospheric aerosols: A review, Rev. Geophys., 38, 513-543, doi:10.1029/1999RG000078, 2000.

Haywood, J. M. and Shine, K. P.: The effect of anthropogenic sulfate and soot aerosol on the clear sky planetary radiation budget, Geophys. Res. Lett., 22(5), 603-606, doi:10.1029/95GL00075, 1995.

Herber, A., Thomason, L. W., Gernandt, H., et al.: Continuous day and night aerosol optical depth observations in the Arctic between 1991 and 1999, J. Geophys. Res., 107(D10), 4097, doi:10.1029/2001JD000536, 2002.

Holben, B. N., Eck, T. F., Slutsker, I., Tanré, D., Buis, J. P., Setzer, A., Vermote, E .F., Reagan, J. A., Kaufman, Y. J., Nakajima, T., Lavenu, F., Jankowiak, I., and Smirnov, A.: AERONET - A federated instrument network and data archive for aerosol characterization, Remote Sens. Environ., 66(1), 1-16, 1998.

IPCC Working Group I Fourth Assessment Report Summary for Policymakers released on 2 February 2007 (http://www.ipcc.ch/ ipccreports/ar4-wg1.htm); the full Working Group I report was released in May 2007.

Kaufman, Y. J., Tanre, D., and Boucher, O.: A satellite view of aerosols in the climate system, Nature, 419, 6903, 215-223, 2002.

Kiss, G., Varga, B., Galambos, I., and Ganszky, I.: Characterization of water-soluble organic matter isolated from atmospheric fine aerosol, J. Geophys. Res., 107(D21), 8339, doi:10.1029/2001JD000603, 2002.

Levy, R. C., Remer, L. A., Mattoo, S., Vermote, E. F., and Kaufman, Y. J.: Second-generation operational algorithm: Retrieval of aerosol properties over land from inversion of Moderate Resolu- tion Imaging Spectroradiometer spectral reflectance, J. Geophys. Res., 112(D13), D13211, doi:10.1029/2006JD007811, 2007.

Law, K. S. and Stohl, A.: Arctic air pollution: Origins and impacts, Science, 315(5818), 1537-1540, 2007.

McArthur, L. J. B., Halliwell, D. H., Niebergall, O. J., O’Neill, N. T., Slusser, J. R., and Wehrli, C.: Field comparison of network Sun photometers, J. Geophys. Res., 108(D19), 4596, doi:10.1029/2002JD002964, 2003.

Myhre, C. Lund and Nielsen C. J,: Optical properties in the UV and visible spectral region of organic acids relevant to tropospheric aerosols, Atmos. Chem. Phys. 4 1759-1769, 2004.

Myhre, G., Bellouin, N., Berglen, T. F., Berntsen, T. K., Boucher, O. et al.: Comparison of the radiative properties and direct radiative effect of aerosols from a global aerosol model and remote sensing data over ocean, Tellus, 59(1), 115-129, 2007.

Myhre, G., Berntsen, T. K., Haywood, J. M. Sundet, J. K., Holben, B. N., Johnsrud, M., and Stordal, F.: Modelling the solar radiative impact of aerosols from biomass burning during the Southern African Regional Science Initiative (SAFARI-2000) experiment, J. Geophys. Res., 108, 8501, doi:10.1029/2002JD002313, 2003a.

Myhre, G., Grini, A., Haywood, J. M., Stordal, F., Chatenet, B., et al.: Modeling the radiative impact of mineral dust during the Saharan Dust Experiment (SHADE) campaign, J. Geophys. Res., 108(D18), 8579, doi:10.1029/2002JD002566, 2003b.

Myhre, G. and Stordal, F.: On the tradeoff of the solar and thermal infrared radiative impact of contrails, Geophys. Res. Lett., 28(16), 3119-3122, 2001.

Nakajima, T., Tonna, G., Rao, R., Kaufman, Y., and Holben, B.: Use of sky-brightness measurements from ground for remote sensing of particulate polydispersions, Appl. Optics, 35, 26722686, 1996.

O’Neill, N. T., Eck, T. F., Holben, B. N., Smirnov, A. A. Royer, Z., and Li, Z.: Optical properties of Boreal Forest Fire Smoke Derived from Sunphotometry, J. Geophys. Res., 107(D11), 4125, doi:10.1029/2001JD000877, 2002.

Pappalardo, G., Bösenberg, J., Amodeo, A., Ansmann, A., Apituley, A., Arboledas, L. A., Balis, D., Böckmann, C., Chaikovsky, A., Comeron, A., Freudenthaler, V., Hansen, G., Mitev, V., Nicolae, D., Papayannis, A., Perrone, M. R., Pietruczuk, A., Pujadas, M., Putaud, J.-P., Ravetta, F., Rizi, V., Simeonov, V., Spinelli, N., Stoyanov, D., Trickl, T., and Wiegner, M.: EARLINET-ASOS: programs and perspectives for the aerosol study on continental scale, Proceedings SPIE, 6367, 5367-6401, 2006.

Pueschel, R. F. and Kinne, S.: Physical and radiative properties of Arctic atmosperic aerosols, Sci. Tot. Environ., 161, 811-824, 1995

Quinn, P. K., Shaw, G., Andrews, E., Dutton, E. G., Ruoho-Airola, T., and Gong, S. L.: Arctic haze: current trends and knowledge gaps, Tellus, 59B, 99-114, 2007.

Ramanathan, V., Crutzen, P.J., Kiehl, J. T., and Rosenfeld, D.: Atmosphere - Aerosols, climate, and the hydrological cycle, Science, 294, 2119-2124, 2001.

Reddy, M. S. , Boucher O., and Balkanski Y., et al.: Aerosol optical depths and direct radiative perturbations by species and source type, Geophys. Res. Lett., 32(12), L12803, doi:10.1029/2004GL021743, 2005.

Reid, J. S., Koppmann, R., Eck, T. F., and Eleuterio, D. P.: A review of biomass burning emissions part II: intensive physical proper- 
ties of biomass burning particles, Atmos. Chem. Phys., 5, 799825,2005 ,

http://www.atmos-chem-phys.net/5/799/2005/.

Schulz, M., Textor, C., Kinne, S., Balkanski, Y., Bauer, S., Berntsen, T., Berglen, T., Boucher, O., Dentener, F., Guibert, S., Isaksen, I. S. A., Iversen, T., Koch, D., Kirkevåg, A., Liu, X., Montanaro, V., Myhre, G., Penner, J. E., Pitari, G., Reddy, S., Seland, Ø., Stier, P., and Takemura, T.: Radiative forcing by aerosols as derived from the AeroCom present-day and pre-industrial simulations, Atmos. Chem. Phys., 6, 5225-5246, 2006,

http://www.atmos-chem-phys.net/6/5225/2006/.

Schkolnik, G., Chand, D., Hoffer, A., Andreae, M. O., Erlick, C., Swietlicki, E., and Rudich, Y.: Constraining the density and complex refractive index of elemental and organic carbon in biomass burning aerosol using optical and chemical measurements, Atmos. Environ., 41(5), 1107-1118, 2007.

Shiobara, M., Yabuki, M., and Kobayashi, H.: A polar cloud analysis based on Micro-pulse Lidar measurements at Ny-Alesund, Svalbard and Syowa, Antarctica, Phys. Chem. Earth, 28(28-32), 1205-1212, 2003.

Shiobara, M., Yabuki, M., Neuber, R., Spinhirne, J. D., Welton E. J., Campbell, J. R., Hart, W. D., and Berkoff, T. A.: Arctic experiment for ICESat/GLAS ground validation with a Micro-Pulse Lidar at Ny-Ålesund, Svalbard, Polar Meteorol. Glaciol., 20, 28 39, 2006.

Smirnov, A., Holben, B. N., Eck, T. F., Dubovik, O., and Slutsker, I.: Cloud Screening and quality control algorithms for the AERONET database, Remote Sens. Environ., 73, 337-349, 2000.

Stohl, A., Andrews, E., Burkhart, J. F., Forster, C., Herber, A., Hoch, S. W., Kowal, D., Lunder, C., Mefford, T., Ogren, J. A., Sharma, S., Spichtinger, N., Stebel, K., Stone, R., Ström, J., Tørseth, K., Wehrli, C., and Yttri, K. E.: Pan-Arctic enhancements of light absorbing aerosol concentrations due to North American boreal forest fires during summer 2004, J. Geophys. Res., 111, D22214, doi:10.1029/2006JD007216, 2006.

Stohl, A., Berg, T., Burkhart, J. F., Fjraa, A. M., Forster, C., Herber, A., Hov, Ø., Lunder, C., McMillan, W. W., Oltmans, S., Shiobara, M., Simpson, D., Solberg, S., Stebel, K., Ström, J., Tørseth, K., Treffeisen, R., Virkkunen, K., and Yttri, K. E.: Arctic smoke - record high air pollution levels in the European Arctic due to agricultural fires in Eastern Europe in spring 2006, Atmos. Chem. Phys., 7, 511-534, 2007,

http://www.atmos-chem-phys.net/7/511/2007/.
Toledano, C.: Climatología de los aerosoles mediante la caracterización de propiedades ópticas y masas de aire en la estación "El Arenosillo" de la red AERONET, PhD Thesis, University of Valladolid, Valladolid (Spain), 2005.

Toledano, C., Cachorro, V., Sorribas, M., Vergaz, R., Berjón, A., De Frutos, A., Antón, M., and Gausa, M.: Aerosol optical depth at ALOMAR Observatory (Andenes, Norway) in summer 2002 and 2003, Tellus, 58B, 218-228, 2006.

Tomasi, C., Vitale, V., Lupi, A., Di Carmine, C., Campanelli, M., Herber, A., Treffeisen, R., Stone, R. S., Andrews, E., Sharma, S., Radionov, V., Von Hoyningen-Huene, W., Stebel, K., Hansen, G., Myhre, C. L., Wehrli, C., Aaltonen, V., Lihavainen, H., Virkkula, A., Hillamo, R., Strøm, J., Toledano, C., Cachorro, V., Ortiz, P., de Frutos, A., Blindheim, S., Frioud, M., Gausa, M., and Zielinsky, T.: Aerosols in Polar Regions, J. Geophys. Res., 112, D16205, doi:10.1029/2007JD008432, 2007.

Treffeisen, R., Turnved, P., Ström, J., Herber, A., Bareiss, J., Helbig, A., Stone, R. S., Hoyningen-Huene, W., Krejci, R., Stohl, A., and Neuber, R.: Arctic smoke - aerosol characteristics during a record air pollution event in the European Arctic and its radiative impact, Atmos. Chem. Phys. Discuss., 7, 2275-2324, 2007, http://www.atmos-chem-phys-discuss.net/7/2275/2007/.

Turpin, B. J. and Lim, H.-J.: Species contributions to $\mathrm{PM}_{2.5}$ mass concentrations: Revisiting common assumptions for estimating organic mass, Aerosol Sci. Tech., 35, 602-610, 2001.

Wandinger, U., Mattis, I., Tesche, M., Ansmann, A., Bösenberg, J., Chaikovski, A., Freudenthaler, V., Komguem, L., Linné, H., Matthias, V., Pelon, J., Sauvage, L., Sobolewski, P., Vaughan, G., an Wiegner,d M.: Air mass modification over Europe: EARLINET aerosol observations from Wales to Belarus, J. Geophys., Res., 109, D24205, doi:10.1029/2004JD005142, 2004.

Wehrli, C.: Calibrations of filter radiometers for determination of atmospheric optical depth, Metrologia, 37, 419-422, 2000.

Welton, E. J., Campbell, J. R., Spinhirne, J. D., and Scott, V. S.: Global monitoring of clouds and aerosols using a network of micro-pulse lidar systems, Proc. Internat. Soc. Opt. Eng., 4153, 151-158, 2001.

Yu, H., Kaufman, Y. J., Chin, M., Feingold, G., Remer, L. A., et al.: A review of measurement-based assessments of the aerosol direct radiative effect and forcing, Atmos. Chem. Phys., 6, 613666, 2006, http://www.atmos-chem-phys.net/6/613/2006/. 